UC.70

Reporting Date: June 1974 Issued: June 1974

\title{
Guidelines for the Interim Storage of AEC-Generated Solid Transuranic Wastes
}

\author{
br $_{Y}$ \\ H-Division Staff \\ Environmental Studies Group \\ Waste Monagement Section
}

scientitic laboratory

of the University of Colifornia

LOS ALAMOS, NEW MEXICO 87544

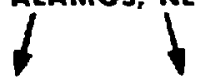


Work supported by the USAEC Division of Waste Management and Transportation.

Printed in the Uniled States of America. Available from National Technical Information Service

U.S. Department of Commerce 5285 Port Royal Road Springtiold, Virginia 22151

Price: Printed Copy \$5.45 Microtiche 51.45 
1. TTHONUCT

II. BACKGROUND 2

III. ASSUMginiloxs 5

IV. DEFINITIORS 3

v. SUMHAY OF GUIDLEIKES

VI. DISCUSSION OF GUIDFIINES 8

A. Establishment of Specifications for Package Materials and Package Construction

b. Package Integri

1. Control of Internal Degradation

2. Control of External Degradation

3. Package Closure 12

c. Exclusions from haste Content 14

1. Mininization of volumes 14

2. Combustible Materials 14

3. Pyrophoric or Explosive Naterials 15

4. Spontaneous Combustion 16

5. Toxic Chemicals 17

6. Free iiquids 17

D. Transuranic Content 18

1. Minimization of Quantities 18

2. Criticality 19

3. Nuclear Heating 21

4. Higher Contamination Levels 22

E. Quality Control 23

1. Packaging Materials 23

2. Final Package 24

F. Fire Control 25

1. Fire Propagation 25

2. Conbustible Materials in Storge
Facility

3. Firebreaks 27

4. Provisions for Firefighting 28

G. Package Handling . 28 
1. Darage to Packages 28

2. Handing Methods 29

3. Control of Transport and Storage
Environgent

4. Radiarion Dose Rate and Contani-
Dation

H. Storage Site Selection and Facility
Design

1. Location - Protention of the
Environent

2. Secondary Barriers $\mathbf{3 4}$

3. Controi of access 35

4. Warma ie Gases

1. Storage Facilizy Operation: $\mathbf{3 6}$

1. Operational procedures $\quad \mathbf{5 6}$

2. Alonitoring 36

3. Acceptance of Packages 38

J. Records and Package Labeling 38

APPEXDIX A: IMULWHA: ACTIOX DIRECTIVI: 0511-21 43

APPENDIX 8: AEC MAXUAL CHAPTER 0511

APPENDIX C: IAHIEDIATE ACTION DIRECTIUE T401-19 
GUIDELINES FOR THE INTERIM STORAGE

OF

AEC-GENERATED SOLID TRANSURANIC WASTES

ABSTRACT

\begin{abstract}
Guidelines have been developed to provide a basis against which to judge the adequacy of techniaues and methods for the retrievable storage of AEC-generated transuranic-contaminated solid wastes. These guide1 ines apply to operations for paciaging, handing, and storage of sucn wastes. Each guideline has been fully discussed with exphasis on the reasoning behind the guideline statement, problews that should be considered in developing a storage facility, and methods currently in use at AEC installations.
\end{abstract}

I. INTRODUCTION

The General Manager of the Atomic Energy Commission (AEC) issued an Immediate Action Directive (IAD 0511-2), see Appendix A) on March 20, 1970, requiring that wastes with known or detectable contamination of transuranic elements be segregated, packaged, and buried in such a fashion that they could be readily retrievable as contamination-free packages within an interin period of 20 years. The directive also specified that retrievability should continue to be possible beyond the 20-year period. The term "known or detectable contamination" was not defined, although a footnote referred to what could be detected by exteralal ueasurements. The Directive acknowledged the need for instrumentation derelopment to improve the lower limits of detection for plutonium compatible with the Directive requirements. The AEC Manual Chapter 0511 (AECM 0511), dated September 19, 1973, uses a lower limit for retrievable storage of ten nanocuries per gran (10 $\mathrm{nCi} / \mathrm{g}$ ) (see Appendix B).

While IAD 0511-21 refers to earth burial of the wastes, implying the package should be designed to meet the conditions encountered in earth burial, AECM 0511 refers to storage of the wastes. The word "storage" is defined as "retention of radioactive waste in some type of man-made device, such as a tank or vault, in a manner peraiting retrieval."

In implezentation of the IAD, it becane apparent that burial of wastes in the comionly used nild-steel drums would not meet the objective of recovery in 20 years due to accelerated corrosion of the drum. As a result, various storage methods have been developed or proposed to keep the packages out of contact with the soil. These include the asphalt pad at the Atlantic Richfield Hanford Company (ARHCO), the Idaho Transuranic Storage Area (ITSA) pad at the National Reactor Testing Station (NRTS), the asphalt-1ined pit at the Los Alamos Scientific Laboratory [LASL), and the culverts at Savannah River. In each of these designs the packages are isolated from direct contact with the soil and are surrounded by air, although the design in each case requires covering the facility with a layer of soil. In essence, this type of facility is a storage warehouse. The questions 
of long-term stability of the physical arrangement of the packages, fire and the spread of fire, criticality, and ventilation and filzering of off-gases from waste decomposition immediately arise. While these conditions are similar to those in plutonium storage areas, the concentrations of transuranic elements in wastes are low compared to materials in storage vaults, there is no defined need for personnel to routinely enter the waste storage facility, and the packaging of wastes and storage conditions are such that the risk of an untoward event, such as a fire, is low. Further, the earth cover provides a degree of protection not found in most storage vaults.

In orier to assist in the implementation of the directives, the AEC commissioned the preparation of the following guidelines. These guidelines are intended to provide the general guidance for the handling and retrievable storage of solid transuranic wastes. As specifications are deve1oped, they can be incorporated into the guidelines. Also, many specific operating guidelines are incorporated in existing AEC Manual Chapters, and no effort has been made to reference all of them in this document. The stated purpose of the AEC in providing the guidelines and the scope of the guidelines are as follows:

Purpose: To provide basic guidelines against which to judge adequacy of techniques and methods being practiced for the retrievable storage of transuranic-contaminated solid waste.

Scope: Covers operations at AEC production facilities for packaging, handling, and storage of retrievable transuranic-contaminated solid wastes (with secondary emphasis on shipment and retrieval). Transuranic wastes also contaminated with significant quantities of beta- ganna enitters are not covered by these guidelines and should be handled as special problems.

Major technological advances in the future will provide additional input which can be utilized in augaenting and updating the currently used interin storage concepts and will lead to a unified waste management progran that combines the interin storage designs with pernanent repository comcepts.

\section{BACKGROUND}

One of the early decisions in the effort to derive these guidelines was that the basis for each guideline be documented as fully as possible. This documentation is intended to assure that adequate consideration is given to important facets of the problew and that the user is provided with additional background information for his interpretation. In cases where no factual information was availabla, the approach taken was to document, as well as possible, the reasoning that led to the guideline. This documentation will serve as an aid to implementation of the suggestions as well.

The general nature of the guidelines permits flexibility in application so that different solutions to the overall problem can be considered and implemented. Many variables are present so that optimized systems can result from trade-offs among those of most importance to the particular installation. Thus, one can choose to specify packages that wili withstand severely corrosive external and internal environments with less concern for control of the corrosive nature of the storage environment or of the waste materials in the package; or one can control the storage envirosment and waste materials and use packaging of lower quality; or one can use a combination of the above. However, it must be recognized that there has been no experience with storage of radioactive waste materials for periods of 20 years or more. Since one cannot rely on proven experience, the assurance 
that the 20-year retrievable storage goal will be met lies in the engineering and operational practices used to implement these guidelines.

Early in the derivation of the guidelines the question of excluding combustible materials from the storage facility was IEviewed. The review indicated that several potential problems in storage of combustible materials could be avoided completely by preoxidation. These potential problems include:

1. The requirement for eliminating certain types of oxidants and other reactive materials from the waste (a requirement difficult to enforce absolutely)

2. The potential of gas formation through pyrolysis or radiolysis leading to possible buildup in an enclosed area

3. The possibility, no matter how remote, of a fire in the storage area. As a result of these considerations, it is obvious that exclusion of combustibles would reduce the risks involved and could simplify the problem of storage. Methods leading to exclusion of combustibles should continue under active investigation. A final decision on exclusion of combustibles will require a more detailed and quantitative study of the various options. In the meantime, such combustibles are being produced and there is currently no proven technology for preoxidizing them. Since current AEC policies require that retrievable transuranic wastes must be stored, the guideline development effort has focused on the innediate goal of providing safe storage of these combustible materials.

\section{I . ASSUMPTIONS}

In the derivation of the guidelines, several assumptions were based upon AEC direction. These assumptions are important since they affect both the nature of the guidelines and the areas of applicability.

1. The guidelines were to be applicable to the wastes from current AEC production or research and development sites. No consideration was to be given at this time to the wastes from commercial power reactors or to wastes buried in comnercial disposal areas. This dictated that the main emphasis was to be on weapons-grade plutomium and heat-grade plutonium and their daughters as the transuranic elements of primary interest.

2. The guidelines were to be general in nature so that individual sites would have freedon to engineer the detailed implementation within the overall framework. Specifications could then be incorporated as they were developed.

3. The lower limit above which wastes were to go to retrievable storage was accepted as the $10-\mathrm{nCi} / \mathrm{g}$ level stated in AECM 0511 .

4. The period of interim storage was accepted as 20 years frum the time of package generation. However, it was recognized that longer periods may be needed if the design of a repository is slower than expected. Also, there may be situations in which shorter periods of storage may be advantageous for economic or safety reasons. The 20-year period was therefore accepted as an overall engineering goal.

\section{DEFINITIONS}

In the development of the guidelines, it has been necessary to define a number of terms. These definitions and discussions of the definitions are given below in alphabetical order.

\section{Combustible}

A "material capable of being burned, except that if the only combustible content of a package is plastic lining or wrapping used for contamination control purposes around incombustible objects or materials, the contents of the package as a whole may be considered noncombustible." (AECM 0511)

A precise definition of the term "combustible" is difficult, if not impossible, to prepare. This difficulty 
arises because the combustible nature of a given material is dependemt not only upon the form of the material but alse on the conditions of ignition which must be considered. Thus, a block of magnesium is normally noncombustible. However, if conditions are right it will ignite and burn with a high temperature. Magnesium turnings will ignite under conditions considerably less drastic than those required for a more massive piece of metal. It is the intent of this definition that emphasis be placed on combustion. However, one should not ignore the long-term phenomena of pyrolysis and thermal decomposition.

This definition of "combustible" is applied to a material under the conditions existing (or possibly foreseen) in the storage facility. Thus, extreme conditions and the method of packaging need not be included as factors in the determination of combustibility of the package. Further, the production of flammable gases need not be a consideration in determining combustibility of the waste material if the control of such gases can be accomplished by separate means. The overall intent of the definition is to consider those materials that may burn in the common sense of the word and that could lead to or add to, a fire if not properly protected. The principal type of material considered as combustible should be the organics, which are composed mostly of hydrogen, carbon, and oxygen. Those materials classed as fire-retardant, either by nature of the composition or because of treatment, should also be included since they will release heat and flammabie gases if exposed to fire from other sources and can, therefore, add to the overall incensity of a fire.

\section{Combustion}

The rapid and self-propagating oxidation of materials in air, with the evolution of significant quantities of heat.

\section{Contanination-Free}

"A condition of the outer surfaces of stored containers, as determined by appropriate swipe surveys or direct radiation instrument surveys, sufficient$1 y$ free of contanimation so that under standard radiatiom work procedures for the sits in question respiratory protectiom will not be required during container lhanding." (AECM 0511)

\section{Interic Storage}

The storage of wastes in a protected area while awaiting transfer to a repository for extended storage or for disposal.

Nonretrievable Solid Transuranic Waste Any solid transuranic waste that contains, or is judged to contain, less than a specified quantity or concentration of transuramic elements (currently $10 \mathrm{mCi} / \mathrm{g}$, as appears in AECM 0511) and that may be disposed of in a nonretrievable manner, but still under conditions tinat will perait control in a disposal area and minimization of any migration of the transuranic elements. Included in this category are wastes contaminated with high beta-gamma emitters.

Normal Retrievable Waste

Wastes containing more than $10 \mathrm{nCi} / \mathrm{g}$ of transuranic isotopes and less than the recovery linit for that type of material as determined by the site.

\section{Process-Generated Wastes}

Those wastes that are generated by, or are the result of, process operations in the enclosure defining the process lines and related equipment. In general, the contamination levels will be significant.

Radioactive riaste

"Materials of no value consisting of, including, or contaminated with radioactive material in excess of the levels or concentrations permitted in AEC Property Management Instructions for unconditional release of excess property." (AECM 0511) 


\section{Recovery}

The reprocessing of contaminated mate-

rials for the purpose of reclaiming and reusing the transuranic elements which they contain.

Repository

"A Federally owned and operated facility for storage or disposal of specific types of radioactive waste from AEC sites and/or licersees." (AECM 0511)

Retrievabie Solid Transuranic Waste

Any solid transuranic waste that contains, or is judged to contain, more than a specified quantity or concentration of transuranic elements (currently $10 \mathrm{nCi} / \mathrm{g}$, as defined in AECM 0511) and must, as a result, be placed into interim storage for evencral disposition.

\section{Retrievable Storage}

"Solid waste generated at AEC sites and containing significant $U-233$ or transuranium nuclide contamination shall be stored at AEC sites, segregated from other radioactively contaminated solid waste and with combustible and noncombustible transuranium-contaminated waste packaged separately. The packaging and storage conditions shall be such that the packages can be readily retrieved in an intact, contaminationfree condition for 20 years. The packages shall be suitably labeled so the waste they contain can be identified by cross reference to permanent records." (AECM 0511)

\section{Room-Generated Wastes}

Those wastes that are generated by, or are the result of, support operations in the room or area containing the transuranic processing facilities. These materials are usually of considerably lower contamination level than wastes generated in process lines.

Scrap

The feed materials for a recovery process, that is, the transuranic- contaninated caterials which are discarded fron a process but which contain sufficient transuranic elements to warrant recovery (see IAD 7401-19, dated May 26, 1971, Appendix ()).

Solid Radioactive waste

Radioactive waste "material that is essentially dry but may contain sorbed radioactive fluid in sufficiently small adounts to be inmobile when buried in dry soil." (AECM 0511)

Solid Transuranic Kaste

Solid radioactive waste "contaminated with certain alpha emitting radionuclides of long half-Iife and high specific radiotoxicity to greater than 10 manocuries/gran (10 microcuries/kilograa)... The radionuclides included are $U-233$ (with its daughter products), plutoniun, and transplutonium nuclides except Pu-238 and Pu-241." (AECM 0511) The inclusion of ${ }^{238} \mathrm{Pu}$ and $241_{\mathrm{Pu}}$ in the requirenents for retrievable storage is at the discretion of the individu 1 storage site. This is considered a policy definition to indicate which naterials are involved, rather than a term definition. The inclusion or non-inclusion of the above mentioned isotopes as transuranic elaments is an individual decision based upon the merits of the case. Thus, the use of the tera Solid Transuranic Waste in the guidelines would apply only to wastes contaminated by those isotopes which by policy, either national or local, require interim storage.

\section{Storage}

"Retention of radioactive waste in some type of man-made device, such as a tank or a vault, in a manner permitting retrieva1." (AECM 0511)

\section{Storage Area}

The area in which the storage facility is located (that is, the site of the storage facility). 


\section{Storage Facili $1 \pm y$}

The actual place of storage of wastes.

This may be an engineered structure such as a building or vault or a protected area in any other type of facility.

\section{Temporary Storage}

The storage of wastes for short periods of time while awaiting transport to or placement in the interid storage facility.

Waste Container

The device or devices, incluting limers and cicsures, used in the packaging of wastes.

Waste Package

The final configuration of the waste in its container as it is ready to be placed into interin storage.

\section{SUMMARY OF GUIDELINES}

Immediately following each guideline, in parentheses, is the page on which the discussion of the guideline will be found. A. Establishinent of Specifications for Package Materials and Package Construction

Engineering specifications shall be estabiished for all packages and packaging materials used for containment of retrievable solid transuranic wastes. (8)

B. Package Integrity

1. Control of Internal Degradation. The combination of waste matrix and waste container shall be such that the package of waste can be readily retrieved in an intact, contamination-free condition for a 20-year period. (9)

\section{Control of External Degradation.}

The combination of waste packaging material and storage environment shall be such that the package can be readily retrieved in an intact, contamination-free condition for a 20-year period. (10)

3. Package Closure. The package closure shall be sturdy enough that it will not be breached under normal handling conditions and will not serve as a weak point for package failure. (12)

c. Exclusions from Wiaste Content

1. Minimization of Volumes. The volume of waste placed in retrievable storage shall be minimized to the greatest extent practicable. (14)

2. Combustible Materials. Conbustible materials shall be excluded from the wastes to the naximum extent practicable. (14)

3. Pyrophoric or Explosive Materials. Positive staps shall be taken to assure that PYrophoric materials, explosive materials, and containers of compressed gases (including aerosol cans) are either excluded from all retrievable wastes or treated to rezove their hazardous properties. (15)

4. Spontaneous Combustion. Positive steps shall be taken to assure that materials that could provide a source of intermal oxygen (such as strong oxidants) or that could lead to spontaneous ignition (such as oils, greases, or solvents absorbed on cellulosic materials) are excluded fron packages containing other combustible wastes. (16)

5. Toxic Chemicals. Highly toxic chemicals and their containers shall receive special handling, treatment, or both, and sha11 not be mixed with other wastes. (17)

6. Free Liquids. Free liquids shall be excluded from all retrievable wastes. (17) D. Transuranic Content

1. Minimization of Quantities. The quantities of transuranic elements placed into retrievable storage shall be minimized to the extent practicable, considering not only the economics of storage and recovery but also the reduction of potential longterm environmental impact. (18)

2. Criticality. The quantity of fissile materials in individual packages shall be limited on the basis of analysis of the potential for criticality in the storage array planned, and in credible accident situations taking into account the actual materials in the waste. (19)

3. Nuclear Heating. The quantity of transuranic elements in an individual 
package shall be limited such that the combination of internal package enwironment and possible waste deterioration from nuclear heating will not adversely affect the containment of the waste package. (21)

4. Higher Contamination Levels. Scrap materials that are reclassified as wastes and wastes containing levels of transuranic contamination above that of normal solid transuranic wastes can be placed into an interim storage facility only after an analysis of the facility shows that the higher level material can be safely stored there. (22)

\section{E. Quality Control}

1. Packaging Materials. A quality assurance program and quality control procedures shall be established to assure that all incoming packaging materials meet the engineering specifications. (23)

2. Final Package. A quality assurance program and quality control procedures shall be established to assure that the final package meets all guidelines and specifications. A seal that must be broken to open the package should be affixed before shipping to the interim storage area. (24) F. Fire Control

1. Fire Propagation. Combustible materials shall be packaged or arranged in storage in such a manner that a fire occurring in cne package will not propagate to another package. (25)

\section{Combustible Materials in Storage}

Facility. The use of combustible materials in the interim storage facility external to the packaged wastes shall be kept to a minimum. When used, any such external combustibles shall not present a possible channel by which a fire can spread beyond the immediate vicinity of its point of origin. (26)

3. Firebreaks. Firebreaks shall be installed at appropriate intervals within the storage facility to prevent spread of fire. (27)

4. Provisions for Firefighting. The operator of the storage facility shall naintain adequate provisions to detect and effectively fight any fire which could occur at the storage facility. (28)

\section{G. Package Handling}

1. Danage to Packages. Packages that are dazaged to a point where the engineesing specifications for the origiral package cannot be assured or where the danage prevent:s conpliance with other guidelines shall not be placed into storage untiI they have been returned to a condition that meets all applicable guidelines. (28)

2. Handiing Methods. All handiing methods for waste packages should be designed to prevent damage to the packages. (29)

3. Control of Transport and Storage Environnent. The storage environment should be controlled to avoid adverse influence on the containment ability of the waste package throughout the handling, transport, and storage of transuranic wastes. (30)

4. Radiation Dose Rate and Contamination. The radiation dose rate and external contaDination levels for the packaged wastes at the time of receipt at the storage faci1 ity, and at the end of the 20 -year period, shall be such that the packages can be handied by individuals within the radiation exposure criteria established in AECM 0524. (31)

\section{H. Storage Site Selection and Facility De- sign}

1. Location - Protection of the Environment. In location and design of the facility an analysis shall be made and documented to provide reasonable assurance that the facility can be operated without undue impact on the environment, that the safety of the workers is adequate, and that the wastes can be retrieved without undue hazard or cost. (32)

2. Secondary Barriers. The design of the storage facility should provide a secondary barrier between the packages (which are regarded as the primary containment) and the groundwater and atmosphere. (34)

3. Control of Access. The area used for the interim storage of transuranic wastes 
shall be adequately controlled to prevent ready access by unauthorized persons. (35)

4. Flammable Gases. The design of the facility sha1l be such that the concentrations of flammable gases, resulting from any waste degradation mechanism, sha11 not reach the lower explosive limit for such gases. (35)

\section{Storage Facility Operation}

1. Operational Procedures. Ali operations of a storage facility shall be covered by an approved and documented procedure. (36)

2. Monitoring. Provision sha11 be made for monitoring of the storage area for radioactive release and other parameters appropriate to the safety of the storage area. (36)

3. Acceptance of Packages. Acceptance standards for packages to be stored shall be defined. Such stankards should include, but not be limited to, the types of packages to be accepted and the information to be supplied. The final decision as to the acceptance of any waste package should rest with the operator of the storage area. (38)

\section{J. Records and Package Labeling}

Each package of waste shall be labeled in such a manner that the package can be identified from a separate set of records. Such labels shall be designed to be legible after 20 years. Minimum information kept in the records shall be as follows:

1. General Information
a. Package Identification
b. Date of Packaging
c. Source of Waste
d. Location of Package in Storage
e. External Radiation Level (neu- tron-ganma)

2. Package Contents

a. Description of Waste Matrix

b. Hazardous Chemical Content

c. Combustible/Noncombustible Designation

d. Estimated Weight and Volume of Contents

e. Transuranic Element Content

\section{Description of Package and Packag- ing Naterial (38)}

\section{DISCUSSION OF GUIDELINES}

A. Establishment of Specifications for Package Materials and Package Construction

\section{Guideline}

Engineering specifications shall be established for all packages and packaging materials used for containment of retrievable solid transuranic wastes.

Many of the factors that influenc: interin storage of transuranic-contaminated solid wastes vary among the AEC waste management sites. The wastes may differ in composition, with significant differences in requirements for packaging, transport, and storage conditions. For this reason, many of the following guidelines are presented as general statesents of goals. In this way, the individual storage location can develop a best overall solution for its specific problens.

In past years, waste materials were buried in areas carefully selected to mininize the possibility of environmental contamination. With the advent of the storage requirements, many burial practices and burial containers have continued in use, with modifications to provide assurance of retrievability. However, the degree of assurance is uncertain because of the lack of both detailed engineering analysis and long-term experience to provide the basis for engineering specifications. A detailed engineering analysis of the packaging and of its suitability for both the contained materials and the storage environment will result in an overall design with adequate safety margins to meet the basic objective. The design will give detailed specifications of materials, protective coatings, liners, and other features needed to permit survival of the package.

An integral part of the engineering analysis will be consideration of the 
trade-offs possible. For example, a solution to the problem of preventing internal package degradation will involve trade-offs between the corrosion resistance of the packaging material and the properties of the waste materials. Treatment of the waste to generate a more inert material will have the effect of altering the specifications for corrosion resistance of the package.

Similar trade-offs will exist between the corrosion-resistant properties of the outer package and the environment where the package will be stored. However, in all considerations of these types, one engineering design goal should be to meet the intent of the guidelines at the lowest cost.

The existence and detail of an engineering analysis and the resulting specifications indicate the degree of attention given to each of the problems of the waste generator. Adequate documentation on the derivation of specifications, including any changes for the waste package and other packaging materials, should be retained.

B. Package Integrity

1. Control of Internal Degradation. Guideline

The combination of waste matrix and waste container shall be such that the package of waste can be readily retrieved in an intact, contamination-free condition for a 20-year period.

Deterioration of the container as a result of reactions with the contained wastes must be limited to assure the survival of the waste package. This limitation can be accomplished by the control of detrimental interactions between the wastes or their decomposition products and the total package (primary container plus liner or package coating). The mechanisms that could lead to deterioration include corrosion, radiolysis, pyrolysis, chemical attack, and, possibly, biological interactions. Due, in part, to the diverse materials in the waste matrix, assessment of potential interactions is conplex; and the solutions are currently uncertain.

Corrosion of the package from an internal source ay be a ajor problem for sone waste types. If external noisture is prewented frow entering the package, dry, inert materials, such as some types of building debris and equipment, should require only structural strength and resistance to external corrosion in packaging to wet the requirements for interim stor" age. Other waste materials, however, have been shown to be incompatible with the containers which have been used for storage. At LASL, sludges fron the 1 iquid waste treatwent plant have accelerated the internal corrosion of unprotected aild-steel drums to r.oduce leaks within one year. 1 corrosion could also result from nitric acid or other chenicals absorbed on the waste materials.

Hany internal corrosion problens could be eliminated, or at least noderated, by the use of soze inner liner or chemicalresistant package coating between the waste and the outer container. Several AEC sites ewploy sose form of internal protection in an attempt to liait corrosion of the primary container. Rocky Flats now uses the 2.29-m liner in drums placed into retrievable storage. 2 Nound Laboratory uses a $0.18-n$ polyethylene liner in drums containing a mixture of sludge and concrete. At ARHCO the drums are internaly coated with a chemical-resistant epoxy finish. 3 An alternate solution wight be the use of a corrosion-resistant primary container, such as a polyethylene drua, for certain highly corrosive waste types. The potential combustibility of such a container would probably confine its use to noncosbustible materials (such as siudges) and might requite a separate storage area from the combustible wastes. Should it become econonically feasible, alteration of corrosive wastes to a more inert form might be the most desirable solution. 
The problem of intersction with the container is not limited to the wastes alone, but also encompasses the products of the degradation of these wastes. Mlajor sources of decomposition include radiolysis and pyrolysis, but the extent of the potential problem from these processes cannoz be fully assessed at this time. The products of radiolysis of matcrials such as cellulosics, plastics, and water are knorn; but the experiments were usually performed using gave: or neutron irradiation. The effects of alpha radiation, with its high energy and limited penetrability, on systems such as these have not been well investigated.

Studies of pyrolysis have demonstrazed the production of gases and smoke at temp. eratures above $150^{\circ} \mathrm{C}$ for typical coabustible waste materials (checsecloth, latex, pol). vinyl chloride, polyethylene). 1 probleas of heating may arise cither from exposure to external heat sources such as solar radiation during temorary storage or from self-heating of the transuranic contaminants, particularly ${ }^{238}$ pu. The possibility of pyrolysis should be decreased, however, by adherence to the guidelines on limitation of the nuclear heat generation and elimination of extreme cxternal tempera. tures.

The products of both radiozysis and pyrolysis may include toxic, corrosive, and flammable gases. Polyvinyl chloride produces HC1, which can corrode cren stainless steel (as would any other chloride contaninant). Polyethylene produces predominant 1 y $\mathrm{H}_{2}$ during rudiclytic degradation, while cellulosics produce various combinations of flammable hydrocarbons and organic acids. The production of these products in sufficient quantities to prove harmful is uncertain, but will depend upon the waste material present. An analysis of the importance of these degradation mechanisms should indicate any necessary provisions for the containment or control of such products. A potential probler associated with such decomposition is the possibility of $a$ breach in the package due to pressurization through gas production. To determine the probability of this situation occurring for any particular waste type will require adequate experimental information on the rates and the extent of gas production under the conditisns prevailing in interia storage. In particular, the possibility of pressurization having occurred nust be considered at the tise of retrieval, whether or not breaching occurs; and caution must be exercised to avoid spread of contamination, especially if the waste material is to be repackaged or processed at that $t$ ime.

Thus, it ill be recessary for the waste producer to exasine the types and combinations of eaterials to be stored. The packaging system wast then be selected for the particulas waste type as based on the potentially detrimental components of the waste zatrix and the possible decomposition products. other guidelines require exclusion of certain materials, such as acids, oxidants, and corrosive chemicals, from the waste watrix to decrease the chances of unfayorable interactions with the package. While the initial specifications derived to $35 s u r e$ compliance with this guideline are likely to be based upon existing waste types, packaging aaterials, and processing techniques, consideration must be given to the development of new processing techniques which could produce other types of waste with different corrosive properties. Any specification derived for present waste types must be revieked at the time of such process changes to assure that the changes in waste form will not invalidate previous conclusions. The specifications finally selected by any waste producer must balance containment ability and economic feasibility.

\section{Control of External Degradation.}

\section{Guideline}

The combination of waste packaging material and storage environment shall be such that the package can be readily retrieved in an intact, contamination- 
free condition for a 20-year period.

If the waste package is to survive for the interim storage period, steps must be taken to protect the package from those external mechanisms that can cause deterioration. These mechanisms include corrosion of metals, aging of plastics, or the decomposition of materials such as wood.

The inability of certain combinations of package and storage environinent to neet retrievable storage requirements has been demonstrated. For example, 210-liter mildsteel drums in shallow earth burial have been breached by the corrosive action of the soil in less than 20 years. Actual predictions of drum lifetimes in such an environment have been given as 3-7 years. 2 Information on the effects of earth burial as a storage environment upon wooden or plastic packaging materials is not presently available, but an untreated wooden package would not be expected to survive under such conditions at many locations. For these reasons the use of earth burial as a method of interim storage has been abandoned at most AEC sites, with waste storage being carried out in such a manner that soils are not in direct contact with the waste packages. However, there is only limited experience upon which to judge the storage environments in use today with respect to the corrosion of presently used packaging materials.

The degree and rate of degradation of a packaging naterial will be dependent upon the material used, any auxiliary protection afforded by a protective coating, and the environment in the storage facility. Specifications selected for any one of these three factors may decrease the need for limitation of the other two. Thus, as a first step, the selection of any working set of conditions requires the definition of those factors in the storage procedure that could influence external corrosion. From such considerations, specifications based upon a balance among the variables can be developed.

Selection of the actual packaging material wust be carefully considered in relation to the storage environment. For example, a wooden box in a damp environment way decompose rapidly, while the same box in a drier, controlled environment may last for wany years. On the other hand, if the environnent of the box is too dry, cracking of the wood way occur. Similarly, an unprotected nild-steel drum will undergo rapid corrosion in a damp atnosphere. Unrelieved stress in the currently used steel drun has been shown in LASL investigations 1 to be an important factor in the rate of corrosion of parts of this container. In this respect, any minor damaze, such as denting of a steel container during handling, transport, or storage operations, may be significant to the survival of the package during the interim storage period.

In the situations described above, some degree of protection may be obtained by the use of preservatives for woods and paints or other coatings for any container materials. In fact, the steel drums used today for waste containnent at AEC sites do have an outer coating of corrosion-resistant paint. ${ }^{2,3}$ However, in the handling of these drums the paint is often badly chipped or scratched. When the coating is undamaged, it has been found to give good long-term protection, even in the more corrosive environment of earth burial. ${ }^{2}$ Wooden boxes used by Rocky Flats for storage of retrieyable wastes at the NRTS are provided with a fiber glass outer coating as a means of protection from externally caused package degradation. ${ }^{4}$ One possible means of avoiding damage during shipment and retaining a complete protective coating on a waste package is the application of the coating to the package immediately prior to storage. Under conditions where a completely undamaged outer coating of known corrosion resistance could be guaranteed, less emphasis need be placed on the construction of the container and on control 
of the storage environment.

Another method of control of external corrosion involves the storage environment itself. For example, strict control of temperature and humidity could ainimize the possibility of external degradation of certain types of packages, resulting in a decreased need for control of the exterior coating system or the type of container construction material. Test ciata should be accumulated to assure that the storage environment is dry or that the packages are not adversely affected by the level of humidity. Alternatively, package protection via protective coating or the use of a corrosion-resistant construction material might provide adequate containment during iaterim storage. In addition, if complete definition of the storage environment is difficult because of the possible changing nature of storage requirements or the lack of facilities (for example, power or water) which are necessary to pernit control, greater emphasis must again be placed on the package and coating systems.

\section{Package Closure.}

\section{Guideline}

The package closure shall be sturdy enough that it wizl not be breached under normal handling conditions and will not serve as a weak point for package failure.

The tightness of the closure mecharism on a waste container is important to the package integrity during handing and storage of retrievable transuranic waste. Health and safety considerations during handing, transport, and storage dictate containment of contamination. It is recognized that some containers are complex in design, with sealed inner containers to provide the containment barrier and with outer containers to serve as protection for the inner container. In any case, a goal for seal tightness should be to provide the protection needed to prevent any spread of contamination during handling, transport, storage, and retrieval.

Process-generated waste is normally removed fron the glovebox by bagging our into $a$ polyvinyl chloride bag, which provides initial containment of contamination. Roon-generated waste in many cases is collected in polyethylene bags, which welid also provide initial containmeat. The requirement that all such waste be sealed in bags or containers before being placed in the storage container provides added protection against contamination spread if the closure of the primary containet should somehow fail. Current evidence indicaces that these swall bags will not survive the 20 years due to degradation by various mechanisns, such as natural aging, chemical attack, radiolysis, and pyrolysis. Thus, this source of protection against coneanination spread vould not be available at the time of retrieval, and dependence would be on the primary container.

While free 1 iquids are excluded from waste placed into storage containers, there are possible mechanisas for separation of 1 iquids or formation of water during storage. From a standpoint of handling, $1 \mathrm{i}$ quid spillage fron containers in storage or at the tixe of retrieval coulu present additional problens of contanination control. While the glideline does not specify gasketing for liquid seal, the assured presence of a closure, even if it should leak to some degree, will minimize these probleas.

Discussion to this point has provided evidence that the storage container should be securely sealed. This guideline does not provide for or recommend an airtight seal, since there are conflicting factors relating to this decision. Considerations that would favor an airtight seal include the elimination of breathing of the package resulting in possible spread of contamination, intake of moisture leading to corrosion, and possible escape of flammable gases. On the other hand, the question of ability to assure a tight seal argues 
against the requirement. Discussion of these points is amplified below.

During temporary storage and transport, variations in temperature and elevation can cause pressurization and depressurization of containcr by as much as \& $14 \mathrm{kPa}$ under certain possible conditions. Gasketed closures on present $1 y$ used DOT 17C or 13H mildstecl dirums will not hold an internal pressurc of $34 \mathrm{kPa}$ for any significant period of time. Thus, package breathing does present a poeential for contamination spread by escape of contaminatien during the "exhale" cycle. Buring storage with relatively corstant pressure and tenperatu.s, one would expect a minimal breathing effect. Degradation of cclunlosics and plastics, however, wight produce sufficicht volumes of gas to grovide a poteritial vehicle for contamination to escape frow the containcr.

In the case of moisture intake from a humid environment by breaching through a closure, corrosion could be considerably different in various configurations, depending on the relationship between the outer container and the inner liner. In the case of the mild-steel drum with a heavy liner, condensation in the annular space could provide a condition for crevice corrosion. Although the heavy iner ay be considered the prinary container in this case, retrieval of such packages with a bady corroded outer container could be difficule.

The most complex consideration relates to gas formation in storage containers. Regardless of exclusions of certain chemicals and waste types (such as pyrophorics), there will be some chemical contanination of the basic waste types. Decomposition of waste materials, in particular the combustibles, through mechanisms such as pyrolysis, radiolysis, and chemical attack can result in gas formation. The quantity of transuranic elements, packing density of the waste material, waste matrix, gature of chemical contaminants, and ambient temperature will have an effect on the type and rate of such gas formation.

If the container is to be tightly scaled (airtight), then it should be designed to hold whatever pressure is developed in a 20-year period. Because of the variables stated above, this pressure is difficult to determine. As a related problen, should an external fire develop near pressurized druns, even greater pressures developed by the heating would increase the probabiitity of rupture, adding flamable gases as well as the contents of the package, if combustible, to the existing fire. This resulting increase in fire-loading external to the package could significantly increase the potential for fire spread. If the container is not airtight, gases could leak into the storage area environment, producing a potential fire conditior. from flammable or explosive gases. Depending on the rates of gas formation, ventilation of the storage facility way be required. The conflicting arguents provide additional support for the elimination of conbustibles in storage, but further studies are needed to wore clearly define the relative problems.

From a practical standpoint, attainment of an airtight container design appears difficult by any means other than a welded closure. Even with inproved designs of gaskets, a seal that will hold required pressures now will not necessarily survive for 20 years. Further, the quality control progran required to assure the seal on each package could be excessive, if not impossible.

When a decision is to be made concerning container design, the previously aentioned factors should be weighed according to the site requirenents for interin storage. Furthermore, future treatment methods that ay produce an inert waste atrix could obviate the necessity for elaborate package designs intended for absolute containment. 


\section{Exclusions from Waste Content}

1. Minimization of Volunes.

\section{Guideline}

The volume of waste placed in retrievable storage shall be ainimized to the greatest extent practicabje.

Large tracts of isolated land areas are becoming less available than in the past for use as waste storage areas. At the same time, long-term surveillance and perpetual mintenance of large storage areas are becoming less practicable and less desirable. For these reasons, the AEC plan for radioactive waste management calls for reduction of the gross velume of wastes generated. In addition, AEC contractors are required to develop volume reduction technology and use volume reduction techniques wherever practicable. 5 Use of volume reduction procedures is also a practical means of reducing the cost of shipping and storing retrievable wastes.

Volume reduction methods are current$1 y$ in routine use at some AEC sites. 1 Procedures at Rocky flats require compaction of wastes and a minimun of $36 \mathrm{~kg}$ per 210 liter drum. Size reduction at several sites is accomplished through cutting large pieces of equipment (such as gloveboxes) to fit into boxes, flattening empty metal containers (both drums and smaller material transfer cans), and crushing filters. Equipment to compact waste materials in drums is being tested before routine employment at both Rocky Flats and ARHCo.

Incineration is another means of reducing the volume of waste sent to retrievable storage. Incineration of combustible wastes for plutonium recovery is presently in use at ARHCO, Rocky Flats, and Los Alamos. In addition, biological wastes are normally ashed at ARHCO. Further development of incineration technology is required before any overall reduction in waste volume can be effected. At the present time, larger quantities of wastes at lower contamination levels may be generated from the ircineration process. Thus, wile the voluae of rezrievable waste is decreased, the overall volume of waste produced ay increase.

\section{Conbustible Materials.}

\section{Guideline}

Conbustible arterials shall be excluded from the wastes to the maximun extent practicable.

The elimination of all combustible wastes from the retrievable storage faci1ity would provide an ideal situation from a fire protection standpoint. The quantities of combustibles external to the packages can be controlled independently to the level where the probability of a fire is nonexistent. However, current studies indicate that the probability of a fire in the facility, even with significant quantities of conbustible wastes present, can be made acceptably low by control of the contents of the packages and by proper packaging techniques. Since the complete exclusion of conbustibles is not a practical objective at this time because of the lack of satisfactory and proven methods of treatment, the guidelines have been derived on the premise that such combustibles will be stored in separate packages from the noncombustibles. 5 It must be admitted that the risk under this situation is higher than under the complete exclusion situation, and intuition would indicate that the risk should increase in some fashion as the amount of combustible materials increases. In addition, the configuration and conditions of the repository, which is to be the eventual resting place of these materials, are not now known. Thus, it cannot be ascertained whether such combustibles can be placed into a repository or whether treatment must be accomplished to reduce them to an inert form. This guideline calls for positive actions to minimize the quantities of such combustibles sent to storage and implies that the vigorous programs of the AEC to provide technology for 
the complete elimination of combustibles through pretreatment or other means shcuid be encouraged.

Actual methods of reducing the volumes of combustible wastes stored include incineration or precombustion by any method and other pretreatment methods such as chenical processing (for example, acid digestion). Considerable developaent is in progress to develop several of these methods for future applications.

Reduction of the volume of combustibles at the source is perhaps the best currently available means of attacking this problem. Techniques which could be considered here include the implementation of waste management procedures at the source of the waste to eliminate all unnecossary combustible materials from the system of operations. This includes, for example, the exclusion from contaminated areas of all packaging materials and other combustibles unnecessury to actual facility operations. Along this same line, a program of decontaminating combustible wastes (for example, rinsing, washing, wiping) in order to reduce the transuranic content below the 10$\mathrm{nCi} / \mathrm{g}$ level may result in some of the combustible waste being disposed of nonretrievajly.

Consideration should also be given to the use of specific types of materials that are more easily treated or disposed of than those currently in use. For example, polyvinyl chloride and other halogenated plastic materials pose corrosion problems in incineration and some other precombustion techniques. The use of alternative types of materials, more easily precombusted, could be of great benefit.

\section{Pyrophoric or Explosive Materials}

\section{Guideline}

Positive steps shall be taken to assure that pyrophcric materials, explosive materials, and containers of compressed gases (including aerosol cans) are either excluded from all retrievable wastes or treated to re- move their hazardous properties.

In assessiag the problens of storage of various anterials, it becones apparent that sone itens that may appear in the waste have properties that make then unacceptable for inclusicn and they aust be handled separatelly, either by treatment to destroy the undesirable properties or by special handling and separate storage from the bulk of the wastes. The materials dezcribed in this guideline are deened to be improper for storage in any facility handling bulk wastes since they not only pose a potential threat to the individual package but could also serve to initiate an incident which could spread to the other wastes, either through direct involvesent of the other waste packages or through the spread of contanination throughout the faci1ity. To implenent the guideline, positive steps for the exclusion of these materials are required since the difficulty of assuring conpliance with conplete exclusion is recognized. It is suggested that these positive steps could include procedural control, with adequate supervision of the procedures and their accomplishment, periodic audits of the contents of waste containers in areas where these materials are used, and control of the quantities of such aterials brought into the area.

The elinination of pyrophoric materials, which could spontaneously ignite under conditions encountered in the handing, transport, and storage, will decrease the probability of fire. Among the pyrophorics often encountered are ferrous oxide, magnesium alloy, white or yellow phosphorous, and sodium. At least one fire has occurred in a drus containing pyrophorics when the drum was exposed to solar heating over an extended period of time. ${ }^{l}$ Although the temperature limitations imposed by these criteria will decrease the chances of ignition in any waste material, pyrophorics exhibit enough uncertainty in behavior to warrant their exclusion from the storage 
facility. Under certain circunstances, uranium and plutonium metals are also pyrophorics but must be considered separately. Only rarely is more than 1 gram of such materials disposed of at one time. The small quantities likely to be found are not considered to present an excessive fire hazard even in the presence of combustible materials.

Explosive and shock or heat sensitive materials shall also be excluded from storage since they may, under some conditions, cause rupture of the package and subsequent spread of activity. The same situation can occur with containers of compressed gases which could rupture upon exposure to heat or shock.

Protection of the integrity of waste packages and the storage facility must be considered for any waste management program. The eventual retrievability of the contaminated wastes will be facilitated by elimination of "high risk" materials, at least in their most hazardous forms, from the storage facility. Such materials should be handled separately as special waste types or treated to remove the risk in storing them.

\section{Spontaneous Combustion.}

\section{Guideline}

Positive steps shall be taken to assure that materials that could provide a source of internal oxygen (such as strong oxidants) or that could lead to spontaneous ignition (such as oils, greases, or solvents absorbed on cellulosic materials) are excluded from packages containing other combustible wastes.

Materials that could lead to ignition or rapid spread of a fire must not be placed into storage. It may be noted that this guideline, again, requires that positive steps on the part of the waste generator and packager be taken to exclude such materials. To some extent, the accomplishment of this goal for these aaterials will be sore difficult than for the explosives or pyruphoriss because of the much wider occurrence of these materials in an operating facility and the consequent higher probability that a towel or rag, for instance, that has been used to clean up a spill of nitric acid will be discarded in the normal waste without adequate neutralization. This will create an added problem in the stipervision of the area to assure that procedures are adequate and are followed.

Himitation of the oxygen available for combustion is one means of minimizing both the chance of a fire and the extent of fire if one does occur. Pure cellulosic materials, rubber, and most plastics contain no oxygen in a form available for combustion and cannot support a fire at oxygen concentrations below about $10 \%$. One way to 1 imit the degree of conbustion is to package these materials tightly enough to 1 imit the degree of combustion. However, the presence of materials that can supply oxygen internally through conbustion or decomposition would merice the effect of the sealed package. Such materials include oxi-

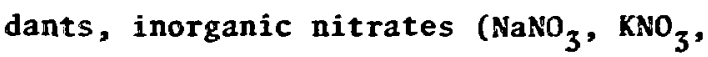
$\mathrm{HNO}_{3}, \mathrm{NH}_{4} \mathrm{NO}_{3}$ ), and cellulose nitrate. Work at Los Alamos and Oak Ridge has indicated that small amounts of nitrate contaminanti at the temperatures ordinarily encountered produce little chance of spontaneous ignition. However, the oxidants may react with other waste materials to effect decomposition and produce flammable gases. Some consideration has been given to excluding air by packaging in an inert atmosphere, but it would be difficult to assure the maintenance of the inert atmosphere over the interim storage period.

Flammable materials, such as organic oils, greases, and solvents, occurring as contaminants on combustible wastes should be eliminated since they represent a possibility of spontaneous ignition. The solvents, with their generally lower flash points, should be disposed of in some more 
permanent manner, such as incineration.

This guideline is not intended to eliminate the disposal of oils and greases by absorbing them on some nomcombustible material (Sorbal, diatomaceous earth, vermicu1ite) and treating the mixture as a solid waste. There are some reservations about this procedure because of the flammability of the oils and greases; but, pending farther tests, the procedure is probably acceptable as long as the residue is well packaged in a noncombustible container with a closure tight enough to minimize the rate of access of air. The guideline is intended, however, to eliminate the placement of such absorbed oils or solvents in the same package with other flammable wastes. Nonflammable oils and greases, such as silicon-based lubricants, can probably be stored with other wastes by sorption on noncombustible materials.

An alternative solution to complete exclusion of these materials is pretreatment of the waste containing this material. For example, nitric acid and certain other oxidants can be neutralized or rinsed from the wastes prior to disposa1. Certain other types of treatment of the wastes, such as compaction or pelletization, might create a condition in which wastes would not ignite even if they were contaminated with flammable materials, such as oils or greases. Further study is required before the reliability or feasibility of any such process could be specified.

\section{Toxic Chemicals}

\section{Guideline}

Highly toxic chemicals and their con tainers shall receive special handiing, treatment, or both, and shall not be mixed with other wastes.

There are many chemicals which may be discarded, frequently in reasonably large quantities, that can lead to problems during handling, transport, storage, or retrieval. These materials include both the corrosive chemicals which can lead, either singly or in combination with other materials and chenicals which may be in the package, to failure of the package. The presence of texic chemicals could unmecessarily complicate handling at the time of retrieval, particularly if repackaging or treatment of the waste is involved. Sich materials present safety hazards to the individuals handing the package. It shou?d be noted that this guideline also includes the original containers in which such materals are received or stored at the laboratory. Such containers may retain a significant quantity of the original contents. Therefore, the unrestricted disposal of such containers into receptacles for other types of waste could lead to a situation where full or nearly full containers could be discarded by the same path by accident or by design.

Highly toxic materials that are contaminated with transuranics require a separate evaluation of the risks involved in storage. Treatment of the chemicals may be necessary to destroy their toxicity. Drums containing large quantities of $\mathrm{KCN}$ have been reported at the NRTS. Such materials should be treated to eliminate their hazardous properties before storage. In addition, containers for such chemicals should be rinsed before disposal to remove a11 remants of the chemical. If it is not possible to make these materials innocuous, the records and/o: labels for the waste packages must clearly indicate the hazardous nature of the contents.

\section{Free Liquids.}

\section{Guideline}

Free liquids shall be excluded from all retrievable wastes.

The term "free liquids" includes any" liquid not absorbed on a solid material such that it will spill or drain from the container in the event of an accident or a loss of internal or external containment. The transuranic isctopes found as contaminants in solid wastes are fairly immobile under 
dry conditions. In the presence of free liquids, however, the transuranics ayy be dissolved and carried frod the contaimers

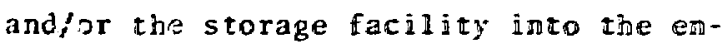
vironment. In addition, if sone conplexing agent is also dissolved in the free liquid, the transuranics ma becone even more mobile.

The exclusion of free $l i q u i d s$ is also desirable from the standpoint of both facility and container stability. For exasple, free organic liquids in the storage facility may increase the fire hazard. Free water, as well as water vapor, will probaldy increase the rate of corrosion of aild-sicel containers. Large quantities of water aight even overcone the rust-inhibiting effects of various protective coatings. Also, the presence of other corrosive 1 iquids aight reduce the containment ability of both the container and the facility.

In addition, the presence of free 1 iquids could present problens in handing. Waste packages will probably not be sealed in a manner to preclude leakage of significant volumes of liquids. Should a package be tipped or dropped during emplacement, contaminated 1 iquid might spil1 onto other containers, fixtures in the storage facili$t y$, or the facility operators.

D. Transuranic Content

1. Minimization of Quantities.

Guidel ine

The quantities of transuranic elenents placed into retrievable storage shall be minimized to the extent practicable, considering not only the economics of storage and recovery but also the reduction of potential long-term environmental impact.

A primary objective of the waste management program at AEC installations is to control the amounts of radioactive materials entering the environment by reducing the quantities of transuranic isotopes stored or disposed of. Among the methods of accomplishing this goal are the foll towing:

1. Treat the wastes to remove the radidactive contamination before they leave the plant, and recycle the recovered transuramic elements.

2. Design processes to minimize transuranic wastes and keep contaminated areas small.

Qbviously, use of the first alternaitie as the sule rethod of control would be expersive and probatly unrealistic. However, any steps, including established decontanimation procedures, to reduce the quantity of tramsuranics in waske will lower the anount that cust go into isolated storage amd hill niminize the contamination potential of an accidental release to Dan's environcent. Reduction of the quantities of contaninants is particularly pertiment in dealing with the long-lived transuranic elements and their daughters, where consideration oust be given to very slow wigration mechanisso, infrequent and large$1 y$ anpredictable changes in the isolation ensironcent, and safeguards against the often unpredictable actions of man, who may hell nake use of environnents currently deened inaccessible. While the interim storage concept includes the possibility of further treatment of the wastes to reduce the transuranic element content at the $t$ ime of retrieval, the establishment of appropriate treatment facilities vill be expensive; and any steps to reduce the mobility of the transuranic elements placed into storage may increase the difficulty of such further treatment. Thus, prudence would dictate that appropriate steps be taken at the time of generation of the waste to reduce the quantities of transuranic elements to the practical minimum.

Currently, the recovery of plutonium is governed primarily by the economic comparison between the cost of recovery and the monetary value of the recovered materia1. External costs resulting from an accidental release of radioactiviry from 
controlled storage, in later retrieval operations, or from permanent storage have not been explicitly included. While such external costs will be small on a per capita basis, and even per unit time basis, they can become significant when considered over the Iifetime of the radioartive naterials, particularly when the factors mentioned above are considered. In adition, the risks posed by potential radiation exposures to the public are less well accepted by society than are the comparable or greater risks from air pollution, pesticides, or the other potentially hazardous agents developed and used by man. This guideline, therefore, states that factors other than the economic value of the recovered product must be included in the decisionmaking process when recovery and recyci ing of transuranic isotopes are considered.

The minimum practical quantity released (or the maximum practical quantity recovered) can only be defined by detailed study of the trade-offs involved in the actual performance of the various processes and the relative value placed on the externalized costs. It is clear, however, that society is placing greater emphasis on the externalized costs every day, and it behooves a governmental agency to take the lead in its practices to fully incorporate these considerations.

It is recognized that with present technology this guideline will appear to be in conflict with a goal of minimizing the waste volume since the recovery processes now used frequently produce a larger volume of waste material than was orijinally present. Since the current recovery processes are not $100 \%$ efficient, this larger volume may still contain contamination but, in some cases, may be below the retrievable limit. Again, trade-offs are necessary, with the possible increased volume and cost of handing this volume balanced against the reduction in risk occasioned by the lower amounts of radioactive materials requiring storage or disposal. In the long run, application of this guideline should lead to inprovenents in recovery processes and critical exanination of each waste strean and its origin, with a view to reducing the total transuranic element content.

The second nethod of minimizing the quantities of transuranic elements placed in retrievable storage involves the institution of good haste Danagement practices in the processing areas. Procedures used in the areas and in the process $I$ ines can be designed to elininate some materials which enter the waste streams. For example, unnecessary packaging naterial, which might becone contaninated in an area where transuranics are handled, could be banned from the process areas. Plutonium production, fabrication, and recovery processes could also be oodified to reduce the amount of contaginated wastes produced.

It should be noted that these guidelines were designed for the interim storage of wastes and not for the overall handing of waste probleas. This guideline refers specifically to interin storage and not the problems of disposal of transuranics in concentrations lower than those specified as requiring storage. In general, dilution of the transuranics to place the final mixture below a concentration limit is an unacceptable practice. Since this guideline deals with very long-lived materials, it is important to recognize that the wording does not imply the minimization of the quantities sent to storage by means such as dilution, and disposal e1sewhere is acceptable.

\section{Criticality.}

\section{Guideline}

The quantity of fissile material in individual packages shall be limited, on the basis of analysis of the potential for criticality in the storage array planned and in credible acci- 
dent situations, taking into account the actual materials in the waste.

Criticality must be considered as a remote, but possible, occurrence in interin storage as several of the transuranic isotopes are fissile, in particular ${ }^{239} \mathrm{Pu}$, ${ }^{241} \mathrm{Pu}$, and ${ }^{233} \mathrm{U}$. In general, current sclid transuranic-contaminated wastes generated at AEC sites do not contain sufficient quantities of the fissionable transuranics to make criticality a serious problem in storage. Other potential problem areas such as general contamination escape, fire, and waste package corrosion have generally overshadowed the question of criticality. Nevertheless, controls must be established to assure against a criticality accident associated with the interim storage of transuranic-contaminated waste materials.

Criticality studies and caIculations predicting sizes of critical arrays have been carried out in detail with regard to applications for Department of Transportation (DOT) Special Permits for shipments of transuranic wastes. These evaluations place limitations upon transuranic and waste content per individual package that can be transported in ATMX Series 500 and Series 600 railcars. Specifically, DOT Special Permit No. 5948 linits the transuranic (fissile) content to $200 \mathrm{~g}$ per 210-1iter drum (or larger), $100 \mathrm{~g}$ per 115-1iter drum, and $200 \mathrm{~g} / \mathrm{m}^{3}$ in crates. No drum may contain more than $90 \mathrm{~kg}$ of graphite. Under these conditions it is not considered possible to have a criticality incident in any transport situation involying transuranic wastes contained in the limited array of an ATMX railcar.

The calculations to support DOT-SP5948 , carried out independently at Rocky Flats ${ }^{6}$ and Mound Laboratory, ${ }^{7}$ assume "worst case" situations for criticality. Each drum was assumed to contain a maximum $200 \mathrm{~g}$ of fissile material and $90 \mathrm{~kg}$ of graphite, and an array of such drums was considered to be fully reflected. Neither calculation took into account the presence of any neutron-absorbing caterials other than the steel druns. Using these assumptions, the calculations show that a cubic array of sinillar druns can becone critical; but the size of such an array is considerably larger than could be present in an ATMX railcat.

Although these calculations showed that transuranic-contaninated wastes can be transported safely in ATMX railcars. they also show that in a "worst case" storage array of such packages, where the number of packages is rot linited, criticality could possibly occur. In fact, however, the DOT 1 initations can be followed in storage with no criticality occurrence because typical waste packages contain a wide variety of aaterials, nany of which are excellent neutron absorbers. Additionally, the assumption that all drabs contain $90 \mathrm{~kg}$ of graphite is highly urrealistic. Calculations made at LASL for "typical" waste materials (for exanple, a gixture of cellulosics, plastic, rubber, and polyvinyl chloride, or chenical treataent sludges) packaged in 210-1iter druns (no liner), each containing $200 \mathrm{~g}$ of fissile material, indicate that they isill not be critical in an array of any size.

Therefore, a suggested guideline to provide for assurance of criticality safety is that the limitations of fissile content of waste packages outlined in DOT-SP-5948 be followed in regard to acceptance of wastes for retrievable storage. For the reason presented above, there should be no possible means by which a critical array of such packages could be formed in any storage situation.

In general, transuranic wastes have not contained quantities of fissile material approaching the $200-\mathrm{g}$ limit, largely due to "in-house" limits set for recovery of transuranics from potential waste materials. On1y an occasional drum of waste sent to the NRTS for storage has contained more than 
$100 \mathrm{~g}$ of fissile material. (None were shipped in the first six montins of 1973.) At less than $100 \mathrm{~g}$ of fissile oaterial, even under "worst case" conditions, criticality cannot cccur.

For the case of transuranic wastes shipped from Rocky Flats to the NRTS, one current requirement is that any 210-1iter drum that contains more than $100 \mathrm{~g}$ of fissile material must be clearly identified by a colored band around the middie of the drum. Any drum so marked must then be isolated from any other similarly marked drum. This results in the physical separation of all packages containing fissile materials at a level for which an array of like packages (under optimal conditions) could conceivably approach a situation of criticality. This precaution is considered to present a generous backup control to the restrictions on fissile content outlined in DOT-SP-5948.

\section{Nuclear Heating.}

\section{Guideline}

The quantity of transuranic elements in an individual package shall be limited such that the combination of internal package environment and possible waste deterioration from nuclear heating will not adversely affect the containment of the waste package.

The effects of heating of either packaged wastes or packaging materials could result in containment loss. For example, it has been shown that $10 \mathrm{~g}$-term heating at even moderate temperatures $\left(50-150^{\circ} \mathrm{C}\right)$ can result in increased rates of waste decomposition, gas formation, and possible package pressurization. For these reasons, the heating of wastes from external sources has been dealt with in a separate guideline. This guideline is specifically directed at heating effects caused by nuclear heating or the energy associated with the radiations (mostly alpha) from the transuranic elements or other radioactive contaminants. Upon anazysis of this problen, soce limitation of quantities of certain transuranic aterials or special control of storage conditions may be necessary. The transuranic isotopes and many of their daughter isotopes decay via emission of high energy (up to $5.5 \mathrm{MeV}$ ) alpha particles. A11 dezay energy is deposited directIy if the waste atrix and the packaging aterials. The calculated thermal outputs of certain transuranics and mixtures of transuranic isotopes are shown in Table '.

These guidelines are limited in scope to consideration of the requirements of only AEC-generated bastes. For the case of weapons-grade plutoniua, a 1 init of $200 \mathrm{~g}$ of fissile aterial per 220-1iter drum is set by BOT as a transport 1 isitation and has been suggested as a guideline for assurance of criticality safety in storage. At this vaximum linitation of $200 \mathrm{~g}$, the total thercal output is about 0.44 watt/package. Assuning conditions of a spherical package 0.90 in diameter , containing a "typical" cellulosic waste matrix (assumed thermal conductivity $=4 \times 10^{2} \mathrm{~W} \cdot \mathrm{m}^{-1} \mathrm{~K}-1$ ) and homogeneous distribution of transuranic contamination throughout the waste matrix, a onedimensional calculation indicates the maxiaum heat rise above ambient temperature at the center of the package will be only about $2.2^{\circ} \mathrm{C}$. It is noted, however, that the possibility of localized heating due to a nonhomogeneous transuranic distribution has not been considered here.

Heat-source plutonium is a greater source of heat on a unit weight basis. In the situation where the $10-n C i / g$ limit is applied to the ${ }^{239} \mathrm{Pu}$ and ${ }^{240} \mathrm{Pu}$ content, the ${ }^{238} \mathrm{Pu}$ in a package containing $36 \mathrm{~kg}$ of waste would be about $16 \mathrm{mg}$ with a heat output equivalent to about $4 \mathrm{~g}$ of ${ }^{239} \mathrm{Pu}$. While this would pose no particular problem from uniform heating, quantities in excess of about 100 times this could result in significant heat loads. Solid particles of ${ }^{238} \mathrm{PuO}_{2}$ are also known to generate temperatures at the surface high enough to 
TABLE I

POKFR OUTPUT OF SOME PLUTONIUM ISOTOPES AMD MIXTURES

\begin{tabular}{|c|c|c|}
\hline Source & Mates/g & Btu/hr-g \\
\hline${ }^{235} \mathrm{Pu}$ (pure) & 0.002 & 0.006 \\
\hline $\begin{array}{l}\text { heapons } z 3 \text { rade } \mathrm{Pu} \\
\left({ }^{4} 4 \hat{O}_{\mathrm{Pu}}\right)\end{array}$ & 0.002 & 0.008 \\
\hline 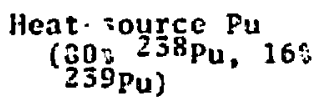 & 0.5 & 2. \\
\hline $\begin{array}{l}\text { High-burnup Pu } \\
\quad\left(68_{0} 259\right)\end{array}$ & 0.01 & 0.03 \\
\hline
\end{tabular}

burn a hole in plastics or other organic materials. This can provide a mechanisn for migration of the particles and for possible penetration of liners or protective coatings.

The thermal analysis required by this guideline can vary in detail depending upon the levels and types of transuranic element encountered in the wastes and the package and storage configuration. For relatively low heat loads a simple analysis such as that given above will suffice. However, where large quantities of transuranic elements with relatively high heat output (such as ${ }^{238} \mathrm{Pu}$ ) are included, detailed calculations both for transport and storage arrays should be made.

\section{Higher Contamination Levels}

\section{Guideline}

Scrap materials that are reclassified as wastes and wastes containing levels of transuranic contamination above that of normal retrievable wastes can be placed into an interim storage facility only after an analys is of the facility shows that the higher level material can be safely stored there.

The classification of materials as "waste" should be based on their negative value relative to recovery-disposal costs. In soce cases, adtinistrative decisions are nade to reclassify scrap daterials containing signjficant quantities of transuranic elevents as baste. This situation nay arise from the current lack of recovery facilities or for other reasons invelving econonics, available storage space, or ninimization of radiation dose to personnel.

If a decision to reclassify "scrap" as "waste" is based upon analys is (or correction of an earlier analysis) that indicates that the transuranic content is within the normal linits of retrievable waste, then the transfer of the material to retrievable storage can proceed. If, however, the actual transuranic content of the material is much higher than in normal retrievable waste, reclassification as waste should not be made until a determination has been made that full costs of storage and eventual disposal of the material as waste have been considered in the decision to abandon the recoverable values.

This guideline is concerned directly with the requirements for safe storage of this higher level waste material, which, because of its much higher level of contamination, has associated with it greater potential risks. For this reason, before the 
higher level waste can be physically transferred to a retrievable storage facility, an analysis of the specific problems associated with its presence in the facility should be made and documented. One of the primary concerns associated with storage of highly contaminated wastes is the increased potential for the spread of contanination should package containment be lost. The breaching of even a single package of such material in a storage facility could result in all packages in the facility becoming highly contaminated.

In the event that the analysis indicates that all applicable guidelines are not satisfied or that the risk associated with the presence of the material in the facility is unacceptably high, the material should be placed into or left in scrap storage until such time as the necessary facilities are made available. At LASL, the NRTS, and Savannah River, a solution involving isolation and modular storage has been applied to this problem. At LASL, for example, a significant quantity of heatsource plutonium has been reclassified as waste, thus requiring retrievable storage. To accomplish this storage, a technique utilizing concrete casks has been instituted. Two packages of the waste material are being sealed in individual casks with each cask then effectively isolating these two packages from all others. At the NRTS, a sizable amount of high-level ${ }^{233} \mathrm{U}$-contaminated waste will be stored on the ITSA pad and will be isolated from all other stored wastes, again limiting the extent of the contamination spread. At Savannah River, concrete culverts $(1.8 \mathrm{~m}$ diam $x$ $1.8 \mathrm{~m}$ high) have been used to contain both high-level wastes and scrap materials (several packages in each culvert). This general technique of isolation or modular storage is sugsested as an excellent guideline for consideration where storage of such highly contaminated wastes must be accomplished.

\section{E. Quality Contro1}

1. Packaging Materials.

\section{Guideline}

A quality assurance progran and qualíty control procedures shall be esteblished to assure that all incoming packaging naterials neet the engineering specifications.

A vital part of the retrievable storage plam is the establishnent of engineering specifications for packaging naterials and for package construction. Such specifications will be based upon the materials to be stored and the expected conditions of storage. In order to obtain assurance that the containers and other packaging materials used fulfill these specifications, it will be mecessary to have a progran of inspection of these itens. Such programs are conmonplace in the nuclear industry and are usually conducted at the tine of receipt. In cases where adequate tests for specifications of the finished container (such as a specification based upon the nethod of banufacture) cannot be devised, inspections are conducted at the nanufacturer's locations. In view of the inportance of the packaging naterials in assuring retrievability of the package and in minimizing package failure, some program of quality inspection and control should be established for these materials. In order to be effective, such a program should start with the purchase contract, which should include the specificaticns that packaging materials will be expected to meet upon receipt.

Past experience has indicated that if quality control procedures are absent, substandard containers might be used. Specifications for $210-1$ iter drums $(17 \mathrm{C} / 17 \mathrm{H})$ have been established by the DOT and have been given to drum vendors. However, many of the drums purchased have not met the specified quality, and these substandard drums have been used for waste storage. Since 1970, Rocky Flats has attempted to correct this situation. ${ }^{2}$ Their specific 
problems with faulty seams and drum-inead sealing surfaces have been corrected through conferences with drum vendors and by establishment of a drum quality acceptance program. These drums are now produced under vendor quality control procedures and are again inspected and tested by the purchaser upon delivery.

One part of the overall quality control program for packaging materials should be a working agreement between the manufacturer and purchaser as to the detail of the manufacturer's quality assurance prograo. Moreover, records of the manufacturer's program should be available to the purchaser for inspection and review. These procedures have been initiated by both Rocky F1ats ${ }^{2}$ and ARHCO. 8

The principal quality control procedures should involve both materials inspection and testing to determine final conpliance with the engineering design specifications. This program need not be an operational part of the waste management program, but could be carried out as a normal function of a materials procurement group.

\section{Final Package.}

\section{Guideline}

A quality assurance program and quality control procedures shall be established at the waste packaging location to assure that the final package meets all guidelines and specifications. A seal that must be broken to open the package should be affixed before shipping to the interim storage area.

The quality assurance program for the packaging materials is designed to provide control of these incoming materials. In the packaging procedure, however, these materials are extensively handled, and the content of the wastes to be placed in storage must be controlled in order to provide an overall package that will meet the requirements for storage. Thus, a quality controll progran intended to ensure that the other guidelines for packaging are indeed followed provides a final overall assurance that the package can safely be sent to the storage facility.

Such a controll program can take many forms depending upon the management philosophy of the organization. Routine checks of the operating procedures can suffice in Dany instances. In others, written assurance from the person in charge of the waste generation area eay provide additional control. In sose cases, it may be desirable to have inspection of each package or spot checks of the contents and assembly of representative packages. An inportant item in the final check is a review of records for each package to assure that all required information is provided, in particular, the transuranic elesent content as measured or estinated by the generator. In addition, quality control procedures nay also be necessary to assure that the guidelines concerning protection of the waste packages during teaporary storage before shipping, during loading procedures, and during transportation to the storage area are met.

The seal for the package should be affixed at the conclusion of this program. This seal may serve several purposes. Firstly, it indicates that tirere has been no removal from or addition to the contents at any stage of the transportation, handing, or storage. It thus provides assurance to the package receiver at the storage facility that there has been no inadvertent or deliberate tampering with the package which could have resulted in a spread of contamination to other packages or to the public when en route. Secondly, the seal may serve as an identification tag for the packase in compliance with the requirements for package labeling. Finally, for off-site shipments it may be attached as a security seal to meet safeguards requirements. 


\section{F. Fire Control}

1. Fire Propagation.

\section{Guideline}

Combustible wastes shall be packaged or arranged in storage in such a manner that a fire occurring in one package will not propagate to another package.

If combustible wastes are placed in retrievable storage, there will be a finite probability of fire. Waste materials are composed of a variety of substances, including chemical contaminants. Therefore, they are potential candidates for spontanems combustion and burning. Minimization of combustible wastes requiring storage and exclusion of materials and chemicals that can initiate combustion reduce the possibility of ignition. Nevertheless, should 3 fire somehow start in an individual waste package, it will be important to ligit spread of the fire beyond its point of ignition.

Several techniques can be used to prevent the spread of fire from one package to arother. The limitation or combustibles external to packaged wastes has been considered as a separate guideline. Others include the packaging of wastes in fireresistant containers, spacing packages of combustible wastes, surrounding combustible waste packages with noncombustible packages, and, possibly, limiting the quantities of combustibles per package. of these, the use of fire-resistant waste packaging appears to offer the best immediate overall solution. Spacing packages of combustibles, which AEC policy requires to be packaged separately from noncombustibles, 5 could result in poor usage of storage space, with a resultant cost increase. Limiting the amount of combustibles in individual packages could effectively reduce the threat of fire spread when fire-resistant waste packaging is employed. The disadvantage of this method is the possibility of large cost increases. Surrounding packages of combustibles with packages of noncombustibles would appear to be a viable technique. In considering fire spread, the place to start is with the waste package itself. Available research shows the usefulness of having the pricary waste package constructed of nonconbustible naterials with reasonably secure package sealing. H. W. Godbee ${ }^{9}$ has carried out studies of cosbustion with clean and cheaically contaninated cellulosic and plastic wastes in 3 -1iter $\left(0.1 \mathrm{ft}^{3}\right)$ plywood boxes and steel containers. While these packages aay have been too small to give neaningful results for larger packages, he concluded that combustible wastes should be secure in nonconbustible containers because there is insufficient oxygen in such containers to allow conbustion to procied to the point where the container could be breached. Sose cosparative studies similar to the one above have been carried out with $3-\square^{3}$ (standard $4^{\prime} \times 4^{\prime} \times 7^{\prime}$ ) fiber glass-coated plywood boxes used to store soce of Rocky Flats' wastes at the NRTS and with uncoated plywood boxes of the same size. ${ }^{4}$ Following ignition there was rapid self-extinguishment in both the coated and uncoated boxes as the oxygen was consumed. The only difference between the two was that the uncoated box was capable of venting the gases produced $b ;$ combustion. These experiments indicate that coppletely airtight sealing is not strictly necessary for fire control. Package venting is allowable so long as the leakage of air into the package is at a rate low enough to minimize additional combustion. In fact, limited venting may be advantageous in preventing a container rupture from pressure buildup.

In the event that a fire in one waste package does succeed in breaching that package, the packaging materials must prevent the contents of adjacent packages from becoming additional fuel. Without additional fuel a fire will self-extinguish. It should be noted that the amount of combustibles external to the packaged wastes within the storage facility, if limited to a maximum 
fire loading of $22000 \mathrm{kcal} / \mathrm{m}^{2}$ suggested in the following guideline, will have only a minor effect on the further spread of a fire originating in wastes contained in a single package in the event of breaching of that package.

There is a pcssible advantage in using small. containers, whatever their specific type, for packaging of combustibles. $3 y$ limiting the package volume, a ligitation is placed upon the magnitude of a worst single package fire which all adjacent packages must withstand. The total heat from such a fire will be important in the potential breaching of adjacent packages of waste, as breaching of noncombustible containers will most likely occur via a pressurization mechanism. Again, this may be an advantage of containers capable of limited venting in that the potential effects of container breaching are prevented.

2. Combustible Materials in Storage Facility.

\section{Guideline}

The use of combustible materials in the interim storage facility external to the packaged wastes shall be kept to a minimum. When used, any such external combustibles shall not present a possible channel by which a fire can spread beyond the immediate vicinity of its point of origin.

An important feature of the storage facility design which may control the spread of any fire in a storage area is the amount, type, and arrangement of combustible materials external to the waste package. The use of such items as wooden pallets, plywood, plastic sheeting, or any other form of combustible material should be carefully reviewed. The ideal situation would involve the elimination of all combustibles external to the waste package in the storage area. However, for economic reasons, waste handling considerations, or other factors specific to a given waste type or storage site operation, this absolute exclusion of external conbustibles nay be neither workable nor fully justifiable. Under these circunstances 1 initations on the amounts and types of uses of external combustibles are desirable in order to assure that no pathway exists for the spread of any possible fire.

On the ITSA pat at the NRTS, single layers of 9.5-n (standard 3/8-in.) fireretardant plywood and plastic sheet are used betweer each layer of 210-1iter drums, and a single layer of 19-co (standard 3/4-in.) fire-retardant plywood and plastic shecting is used to cover the waste packages on the pad to keep soil frop coning into contact with the packages. In the $V$-trench at A.4ACO, no naterial was used to separate layers of druns. and cetal sheeting was used as cover to prevent soil-package contact. Sinilarly, at Savannah River no combustible materials are used external to the waste packages stored in the concrete culverts.

Even the use of fire-retardant treatcd combustibles does not guarantee safety in storage. Treated naterials such as woods can, in time, lose their fire-retardant properties through such natural aging processes as cracking of the wood, separation of layers, and other decomposition processes. Nevertheless, some limited benefit may be derived by the use of only fire-retardant treated combustibles where the external use of these combustibles is desirable.

One general rule applying to the use of external combustibles in a storage facility is that such materials should only be used where absolutely necessary and then within limits of an allowable external fire loading. A suggested guideline for limitation of external combustibles in the storage facility is that their use be confined to layers, each having a maximum fire loading of $22000 \mathrm{kcal} / \mathrm{m}^{2}$. Adherence to this guideline would limit the heat produced in a fire of external origin to a point where waste containers, if metal, would not be weakened or ruptured. The maximum temperature for such a condition would be 
approximately $430^{\circ} \mathrm{C}$ for a period of less than five minutes. The heat-sink capability of metal containers would peroit absorp$t i o n$ and dissipation of this heat rapidly enough to reduce any possibility of container rupture. A listing of the approximate heat content values for typical types of materials that may be considered follows:
Cellulosic Materials

Polyvinyl Chloride

Rubber

Plastics
$4200 \mathrm{kcal} / \mathrm{kg}$

$5300 \mathrm{kcal} / \mathrm{kg}$

$8600 \mathrm{kcal} / \mathrm{kg}$

$8900-9400 \mathrm{kcal} / \mathrm{kg}$
Layers should be separated from each other by at least 1 meter of noncombustibles and/or air. Combustibles sealed in a noncombustible package are considered a noncombustible layer. However, under some circumstances a primary package constructed of combustible materials may be used for certain waste types. For example, consideration might be given to the use of polyethylene or other plastic container for storage of process sludges. Under the restriction of this guideline, however, any combustible primary waste packaging materials must be included in the determination of the $22000-\mathrm{kcal} / \mathrm{m}^{2}$ limitation.

Despite the precautions and Iimitations discussed above, there is no guarantee that a fire external to the packages will not propagate through external combustibles. Sheets of plywood between layers of packages probably will not prevent a fire from spreading upward. Therefore, consideration should be given to the use of noncombustible materials such as metal sheeting, Transite (asbestos) board, or thin fiber glass sheeting.

\section{Firebreaks.}

\section{Guideline}

Firebreaks shall be installed at appropriate intervals within the storage facility to prevent the spread of fire.
The use of firebreaks in a storage facility containing conbustible wastes is a basic technique to separate the storage area into smaller sections of risk. At the same tine, the firebreaks can serve to limit the amount of air in each codule. At the present tide, the use of firebreaks is employed on the ITSA pad, where a I-meter wall of soil is used to separate "cells" on the pad, each cell 1 seasuring $24 \mathrm{~m} \times 46 \mathrm{~m} \times 4.6 \mathrm{~m}$ [about $1100 \mathrm{a}^{2}$ or $5100 \mathrm{a}^{3}$ ). Similarly, the prototype Eodel of the $V$-trench at ARHCO was designed to have four compartments, each 7.6 in length. This compartmented construction was, however, not followed through in the facility construction.

Many factors influence the need for and the size of areas to be separated by the use of firebreaks. The "need for" decision will depend upon the voluce of actual combustible naterials that must be stored. For the case where larger amounts of combustibles are present, decisions on limits for storage facility size should include consideration of fire loading within a given area; 1 initation on the anounts of contained transuranics; threat of fire; and costs of clean-up, decontamination, and repackaging of material should a serious fire sodehow occur. Note: AECM 0552 states: "Potential losses from a single fire exceeding $\$ 100000$ are comonly viewed with serious concern while maximum potential losses exceeding $\$ 1000000$ are considered unacceptable.")

In establishing firebreaks, it is possible that some advantage could be derived from the proper intermixing of packages of combustible wastes with packages of noncombustible wastes in the storage area. In this way, the packaged noncombustibles might effectively provide a form of "internal" firebreak through separation of larger volumes of the packaged combustibles. This technique could be implemented through the stacking of combustibles and noncombustibles in alternate rows or by the estab1ishment of smali "pockets" of 
combustibles separated by noncombustibles. In each case the effect would be to separate the stored combustibles into smaller groups to prevent the spread of a fire.

\section{Provisions for Firefighting.}

\section{Guideline}

The operator of the storage facility shall maintain adequate provisions to detect and effectively fight any fire which could occur at the storage faciiity.

Provided that al1 of the other guidelines regarding the prevention of fire within the stored wastes are followed, there should be assurance that any fire of serious consequence will not occur. Nevertheless, as added insurance there should be adequate means available to detect a fire and fight it and a capability of extinguishing the "worst case" fire.

Adequate provisions to fight a fire inciude the development of procedures for fighting fires in contaminated waste areas, as well as the availability of equipment and resources to fight a fire. A plan for the storage facility, in particular, should establish procedures for fighting fires in radioactively contaminated materials. The prime concern fore is the immediate protection and safety of the personnel involved. Training of the personnel in such procedures is vital.

Equipment available may include standard firefighting equipment either from a nearby community or at the site itself if the site is isolated. For the case of an engineered storage facility, equipment could include an extinguisher syscem, such as a sprinkler system or perhaps an inert gas blanket, installed in the faciiity. Where wastes may be stored in a "facility" involving the use of an earth covering, earth moving equipment capable of keeping the facility enclosed, thus extinguishing the fire by cutting off the air supply, should also be available.
Finally, wherever there is a need for water as part of the firefighting requirezemts, provision cust be nade to have a water line leading directly to the storage site or to have adequate water storage at the site. Should a fire occur, consideration should be given to collecting and holding the spent water for monitoring and controlled disposal. If an inert gas blanket is used, consideration should be given to the meed for filtering the gas to prevent escape of a: rborme contanination.

G. Package Hand1ing

1. Danage to Packages.

\section{Guidelime}

Packages that are danaged to a point where the engimeering specifications for the original package cannot be asSa: sed or where the darage prevents compliance with other applicable guidelines shall not be placed into storage until they have been returned to a condition that neets all applicable guide1 ines.

other guidelines have laid the basis for packages and their storage environments to neet the objective of retrievable storage. However, careful attention to all of these natters can be invalidated if packages are accepted in such a damaged condition that they would not meet the requirenents for the finished package. The operator of the storage facility should, therefore, provide sone package inspection and make provisions to reject or repair any packages that have been damaged beyond this point.

Certain types of damage to the container, to the seal, or to any additional protective coating might negate the engineering design and prevent the total package from meeting the goal of retrievability. Any damage incurred must not significantly reduce the ability of the package to survive under the conditions of storage. Thus, if a surface coating is necessary to control the external corrosion rate of a mild-steel 
drum, scratched areas might recuce the life of the package. Dents might create stress areas which, if unrelieved, might serve as focal points for stress corrosion or stressaccelerated corrosion. Severe denting or crushing of metal containers will reduce the ability of the package to withstand even norma 1 handling and may yiolate the imfegrity of the seal, thus increasing the possibility of contamination release. Fiber glass-coated plywood boxes may be scraped severely enough to expose the plywood.

The storage facility operator is responsible for the retrievability of the waste packages once they have been accepted at the facility. Since he will also be most familiar with the conditions at the facility, the responsibility of determining whether or not any package will remain intact for the 20-year period must rest with him. Unless the engineering specifications have provided a margin of safety with res pect to possible damage, packages that the storage facility operator finds to be damaged beyond the specifications will require repair prior to storage. Such repair may take the form of either complete repackaging or, if possible, treatment to eliminate the damage.

Damage to a necessary external coating applied before shipment could be repaired by recoating the packages at the storage facility. Recoating can repair a large percentage of any scratched areas, but would not necessarily prevent localized stress corrosion in areas of more severe damage. Careful checking of the packages for contamination before shipping, and also at the time of receipt, would assure that no unacceptable level of surface concamination is covered by the coating. The cost of either repair or repackaging made necessary by damage incurred prior to acceptance at the storage facility should be borne by the waste generator.

An alternative solution involves the shipment of uncoated packages to the storage facility, where they could then be coated. Any decision to follow this course of action would require cooperative action on the paits of both the waste generator and the storage facility operator.

\section{Hand1ing Methods.}

\section{Guideline}

All handing nethods for waste packages should be designed to prevent damage to the packages.

In order to nininize the number of packazes rejected because of handling damage, the mandling bethods for the package anst be considered as a part of the entire systes. Poorly designed transport and handIimg techniques imcrease the chances of danage wich will inpair the ability of the package to survive the interim storage period.

In the past, transport methods have resulted in varying degrees of damage to the packages. "Hurnping" of the ATMX railcars containing druns fron Rocky Flats previously had dented, crushed, or buckled the packages. Mlost of this damage has been alleviated as a result of studies of acceleration: encountered and by the incorporation of cushioning devices such as airbags. Another systen that helps protect waste packages in transport is the use of inner cargo containers within the ATMX cars. These inner containers also provide a simple method of removing the packages from the railcar and serve to reduce possible damage incurred during on-site transport from the rail area to the storage facility.

Handling of the packages during loading, unloading, and placement procedures is frequently effected through use of a forklift. Careless operation of the forklift may resuit in punctured packages. At the NRTS the forklifts have been modified by the addition of a device which encircles two drums and places them on the stack. This system eliminates the danger of puncture but does result in some paint loss. Another method that reduces the chances of a punctured package is the 
use of pallets. At LASI, four druns of momretrievable liquid waste treatnent sludge are banded together on a nooden pallet. This unit is then lifted, with the forllift contacting only the pallet.

Handing of the packages at various stages of the storage operation showid mot contribute to the deterioration of those packages. A safe, economical method of handling should be developed in conjugction wit. the design of the parkage to assure that the engineering specifications cont isue to be met throughout the interin storage period.

\section{Control of Transport and Storage Environment}

\section{Guideline}

The storage environment should be controlled to avoid adverse insluemce on the containment ability of the waste package throughout the handling, transport, and storage of transuranic wastes.

The packaging of wastes at norcal roon temperatures and moderate humidities should present no particular problen for the generally encountered waste types, including combustibles. However, extrene temperatures and humidities at any point in the overall handling, transport, and storage procedure can result in harmful reactions in the waste or packaging materials. These reactions may result in destruction of some part of the package or decomposition or reaction of the contained wastes. Limiting the temperatures and humidities to which the waste package is exposed should minimize the extent of such potential sources of package degradation.

Most present methods of interim storage, which utilize a cover of a meter or more of earth, probably will protest the stored wastes from temperature extremes since the soil is a fairly good insulator. 10 However, depending upon prevailing climatic conditions, any proposed above-ground storage structures could require tenperature control systems. In any case, maxirim amd 口îninum expected temperatures during amy storage operation must be controlled within reasomable 1 inits. No direct designation of temperature ranges is made here because of the diverse nature of the wastes and the unknown rethods of packaging which aay be used in the future.

However, extrenes in temperature may cause problems during handling, transport, and temporary storage. One problem that Day be encountered is the softening and melting of polyethylene 1 iners in the waste packages. This will accur between about $100^{\circ} \mathrm{C}$ and $150^{\circ} \mathrm{C}$ (depending upon the density of the palyethylene). 11 The 2.29 -mn polyethyleme limer is intended to serve as the privary contaimer should the steel overpack fail. Excessive heating can cause structural weakening of, and possible loss of containtent by, the polyethylene, thereby negating the purpose $o_{i}$ such a liner. Loss of containment ability could occur for the less rigid polyethylene Iiners and for the polyvinyl chloride bags used to protect process-generated wastes.

Another possibility of reaction from excessive heating occurs within the waste atrix. Increased temperatures might accelerate both theraal decomposition and chemical reactions of the wastes. The major constituents of the combustible wastes -cellulosics, polyethylene, and polyvinyl chloride - are known to pyrolyze, with the production of various corrosive and flammable gases. Polyvinyl chloride decomposes above $100^{\circ} \mathrm{C}$ to produce $\mathrm{HCl}$, which miy attack the wastes, the liner, or the outer container if the liner is breached. Cellulosics and polyethylere begin to decompose above $270^{\circ} \mathrm{C}$ to yield hydrogen, flammable hydrocarbons, and organic acids. 11 The presence of the flammable gases is undesirable since it would result in a design constraint on the storage facility to prevent accumulation. The National Fire Protection Association suggests that about $66^{\circ} \mathrm{C}$ is the highest safe temperature to which wood, a primary source of cellulose, 
can be continuously exposed. 11 In addition to the possible problems created by the chemical properties of the evolved gases, their presence can pressurize the package. Evolution of sufficient volumes of gases, or the presence of sufficient heat to cause expansion of the contained gases, may also result in breaching of the package.

One of the major factors to be considered in this guideline is direct or indirect solar heating. Temperature control precludes heating of the packages by direct exposure to the sun, such as frequently occurs during temporary storage and transport. Fires due to solar heating of drums containing pyrophorics from Rocky Flats ${ }^{1}$ and conbustibles at ARtrC have been reported. In areas of intense solar radiation, temperatures inside black drums can exceet $100^{\circ} \mathrm{C}$ in the summer. Shipping or storing of wastes in enclosed facilities which can be heated excessively by solar radiation should also be avoided. Alternatively, the use of light-colored packages may minimize solar heating effects.

In storage areas where prolonged periods of subfreezing weather are encountered, some consideration should be given to the effects of extreme cold on certain waste types. For example, freezing and thawing of sludges, which contain $60 \%$ or more water, could cause separation of some free water from the solid material. In fact, the British and the Russians utilize natural freezing and thawing of their liquid treatment plant sludges to increase the sludge particle size and to effect settling prior to filtration. ${ }^{12}$ Whether a separation would occur in the wastes and whether it would be hazardous to the storage facility is unknown. However, the very uncertainty that exists with respect to problems incurred at extremely low temperatures indicates a need to consider their occurrence during transport and within the storage facility.

Excessively high humidities may also cause containment problems, especially through enhancenent of corrosion rates of container aaterials. Unprotected mild steel, or painted aild steel that has been scratched and dented, is highly susceptible to corrosion. Several rust-inhibiting coatings can successfully eliminate or limit corrosion of pild steel. However, an altermate solution may be control of the humidity to which the packages are exposed. In either case, the corrosive effects of high humidities (including exposure to rain or snow) should be liaited both before and after packages are placed in the storage facility.

4. Radiation Dose Rate and Contamimation.

\section{Guideline}

The radiation dose rate and external contanination levels for the packaged wastes at the time of receipt at the storage facility, and at the end of the 20-year storage period, shall be such that the packages can be handled by individuals within thi: radiation exposure criteria established in AECM 0524 .

For the safety of individuals shipping, handling, and storing transuranic wastes, the radiation levels and removable external contamination to which these individuals may be exposed must be controlled. haximum allowable levels of radiation exposure to such individuals are established in $A E C M$ 0524. It is the obligation of waste management personnel to implement procedures to assure the safety of all operations personnel in the handling of the contaminated wastes.

Techniques are available which singly or in combination can provide the necessary controls. These techniques include:

1. Limitarion of quantities of contaminants per waste package

2. Adequate package shielding

3 . Waste handing procedures and methods that will not unnecessarily expose personnel involved. 
All of these techniques shall be utilized to ensure that the internal and external radiation dose incurred by facility personnel during storage or retrieval shall be kept as low as practicable and within lioits set forth in AECM 0524. Since waste form, packaging requirements, contamination level, isotopic composition, and other radioactive isotopes present will vary for different waste generation sites, the use of these methods will also vary. For example, if weapons-grade plutonium is the only waste contained for storage, it is unlikely that the external radiation flux will present a handling problem. On the other hand, containers of high activity heat-source plutonium or of $233_{\mathrm{U}}$ containing $232_{\mathrm{v}}$ wil $\mathrm{I}$ require procedures dictating greater control in order to protect persongel.

The waste handling procedures will include monitoring to ensure that adequate safety measures are being taken as well as to define the need for precautionary measures. Along the same lines, records of the isotopic transuranic content of the waste and a description of the package will be utilized in establishing the necessary safety precautions. Consideration should also be given to possible future increases in the external radiation flux (for example, at the end of the 20-year storage period) arising from the ingrowth of daughter products of certain transuraic nuclides and to the influence of this ingrowth of activity on later hand ing procedures.

Depending on the on-site handling procedures of the packaged wastes, two major sources of external radiation exposures are evident :

1. Whole body exposure - a prime consideration for personnel involved in mechanical manipulation of waste or for personnel remaining in the storage area for long periods of time

2. Hand and forearm exposure - a major consideration in hand manipulation of smaller containers.
Inicits for recovable external package contanination are not specifically out 1 ined in AECM 0524. However, the DOT requirebents for shipeent of radioactive materials do set forth gross surface contamination 1inits. These linits must be met for any waste packages being shipped off-site. They nay be applied to on-site storage in the absemce of core restrictive on-site controls. These 1 inits have been inplemented by the transportation industry without apparent difficulty.

H. Storage Site Selection and Facility Design

1. Location - Protection of the Environcent.

\section{Guidel ine}

In location and design of the storage facility an analysis shall be made and docunented to provide reasonable assurance that the facility can be operated without undue inpact on the environnent, that the safety of the workers is adequate, and that the wastes can be retrieved without undue hazard or cost.

Because of the remote possibility of an accident at the facility, selection of a site for transuranic waste storage requires consideration of the public welfare, as we11 as some degree of public convenience. Attainment of this goal requires an analysis of factors of both an environmental impact statement and a safety analysis repor:. When the study has teen made and docunented, it should then be possible to balance the various factors and select an optimum location and design for the storage facility. This analysis should also identify those ongoing monitoring programs needed to demonstrate the reasonable assurance of safety.

An important determination in the selection of any site for a storage faciIity is the identification of mechanisms and pathways by which contamination could be transported to man's environment. 
Analyses of both regional and local site ecology, hydrology, meteorology, geology, and seismicity will provide the inputs necessary to these determinations.

The planning of a storage facility will require both the identification of natural phenomena in a proposed area and the determination of the probability of occurrence and the magnitude expected. These data cam then be used in the determination of the adequacy of a proposed site and construction requirements to assure contaiment diving interim storage.

Assuming that all the above considerations have been satisfied, the actual threat to the storage facility from a major earthquake will be small. The most important consideration is that any stcrage facility should not be located on a major active fault. At a distance from such a fault, the primary effects of a possible earthquake would be movement of the packages and, perhaps, minor damage. Prevention of damage in this situation could be effected through packaging and stacking methods. The methods of storage currently being used at various $A E C$ installations include the use of close-packed stacking arrays which could minimize shifting of the packages during an earthquake. If such wastes were stored in a manner that provided considerable free space, they could fall, with the possible result of some damage to the packages. However, if the packages used actually meet the specifications required for transport, a minor amount of shifting or tumbling may be inconsequential. Finally, even the breaching of several packages would not necessari1y lead to a major spread of contamination within the facility. However, the possible need to repackage or restack some packages following a major earthquake should be considered.

Flooding of a storage site could spread contamination to adjacent areas. This problem may be most serious if contamination borne by flood waters is carried into lakes or rivers. In an arid climate the the possibility of flash flooding in gullies or other depressions exists. Steps should be taken to provide adequate slope and surface drainage to avoid water collection. Proper landscaping of the area, including the construction of dikes or other flood control devices, should be considered where mecessary. Along these sape lines, both the depth of the water table and any possible covecent and fluctuations in depth of the water table zust be considered.

The possibility of violent wind storms, such as tormadoes, nust be considered, although such events would probably have 1 imited effect upon the storage facilities in use today once they have been closed off. Of particular interest, however, is the method of tesporary storage before the wastes are transported or placed into the storage faci1ity. Here the packages are frequently stacked in a location that exposes them to the weather. Wastes stored in this manner are particularly vulnerable to violent winds, and the advisability of using open storage of this type will depend on the wind conditions expected. In addition, the open end of facilities such as the ITSA pad and the proposed aspha1t-lined pit at LASL may be especialiy susceptible to violent winds. For earth-covered facilities landscaping and soil fixation will prevent soil erosion and minimize the chances that the wastes will be uncovered. For example, erosion-retardant grasses currently are used at ARHCO and NRTS to prevent soil movement.

Another possible area for concern would be any ecological consequences (both radiological and nonradiological) of construction and/or operation of the proposed storage facility. Here, however, it must be noted that there are no planned releases of radioactive or chemical contaminants at the storage facility, nor would significant doses of penetrating radiation be expected outside of the actual facility.

There are three closely interrelated factors that require more detailed analy. sis: population distribution in the 
surrounding area, transportation requirements of the waste material, and land usage. The population density in the proposed area should be smail enough that the overall consequences of even an improbable accident will be small. This need suggests not only that the facility should be located in a sparsely populated area, but that there should also be a suitable buffer zone of unused land between the facility and the nearest habitation. Such conditions do prevail at most $A E C$ facilities, where the storage areas are located on large government reservations.

The second factor to be considered is transportation availability and routing for the movement of waste materials from the generation site to the storage facility. The method of transportation used must be selected to ensure the greatest safety to the general public.

The third factor, present land usage, is also inherently related to public welfare and convenience. Consideration must be given to the protection of land being put to profitable or recreational use. The use of public or private recreational lands should also be avoided to minimize interference with the rights of the public. A strong argument can be made for the possible use of land containing facilities previous1y used for other nuclear activities and which may already be contaminated, thereby requiring permanent custody and perpetual care.

\section{Secondary Barriers}

\section{Guideline}

The design of the storage facility should provide a secondary barrier between the packages (which are regarded as the primary containment) and the groundwater and atmosphere.

While massive failures of waste packages are not expected, it is prudent to design the storage facility so that uncontrolled release of contamination will not occur even in minor failures. The primary escape pathways are air and water. Some method of secondary containment should be considered to prevent leakage into the environnemt. The secondary contaimment could also serve to support the waste packages in the facility.

Secondary containment for packages of Iransuranic-contaninated wastes has been inplecemted at AEC sites in several ways. At ARHCD, when the concrete-1ined $V$-trench was filled with packaged wastes, it was covered with getal sheet and $1.2 \mathrm{~m}$ of soil. At the MRTS the procedure is similar. Here, wastes are stored on an asphalt pad and emclosed with layers of plastic sheet, plywood, and approxinately 1 meter of soil. At Savammah River, druns of waste are enclosed in concrete culverts which are sealed at both ends and buried. Each of these systems prevents ready release of moisture to the environnent and can provide a means of collecting any noisture for monitoring.

When filled and covered, each of the above storage facilities may be a nonventilated unit. The possible production and buildup of combustible gases from radiolys is and other waste degradation mechanisms in such an enclosed storage area must be considered. Ventilation of the facility may be required if the concentration of such gases attains a level of $10 \%$ of the lower explosive linit. Under these conditions the use of HEPA filtration may be necessary to maintain an adequate degree of secondary containment.

The problem of free water entering the storage facility has been considered as a part of the engineering design for storage at ARHCO and NRTS. Thus, at both sites the actual facility (the secondary containment) is such that any free water within the facility will drain to a collection point where the water will be held for analysis prior to possible release. Provision for collection of runoff water is suggested for the design of secondary containment methods. 


\section{Control of Access.}

\section{Guideline}

The area used for the interit storage of transuranic wastes shall be adequately controlied to prevent ready access by unauthorized persons.

The area selected for the interim storage of AEC-generated transuranic wastes will be on land owned by the Federal govermment and identified by the posting of appropriate signs. This, in itself, can provide some control of public access to the storage facility. It does not, however, preclude entry, either accidental or deliberate. The presence of contaminated material can present a potential hazard through direct exposure to trespassers. If the trespasser removes contaminated material from the facility, he may indirectly expose others.

Although the storage facility, especially after it is filled, should prevent ready access to any of the contaminated materials, there is still the chance of exposure to transuranics (or any products of degradation of the waste materials) should an unsuspecting person engage in some activities in the area. In addition, the possibility of deliberate removal of materials exists. For example, some tool or piece of equipment might invite theft, or contaminated material might be removed for political or criminal purposes.

In order to prevent any public access to contaminated material, adequate control procedures must be instigated. It is not sufficient that the storage facility be on a fenced government reservation. Adequate surveillance is not feasible for the large areas included in many of these reservations. Also, many people not acquainted with the storage facility have access to such areas. Instead, the immediate area about the facility should be fenced in such a manner that individuals cannot readily enter, either accidentally or deliberately.

\section{Flamable Gases.}

\section{Guideline}

The design of the facility shall be such that the concentration of flamaable gases, resulting from any waste degradaticn nechanism, shall not reach the lower explosive limit for such gases.

It is known from laboratory experiDentation that flarmable gases are generated from radiolysis, pyrolysis, and other waste degradation pechanisms operating upon typical solid waste natrices, such as cellulose, polyethylene, polyvinyl chloride, other plastics, rubber, and even water. For example, $\mathrm{H}_{2}$ is a major product of radiolysis for aost of the above materials. In addition, radiclysis of cellulose, as well as of some rubber and plastic materials, can generate significant quantities of low nolecular weight gaseous hydrocarbons. Flanable mixtures of these products in air are found to range from about 28 to 86 of the gas by volume. For $\mathrm{H}_{2}$ a mixture of 4 \% by volume in air is combustible.

Several problens exist in at:empting to correlate the results of laboratory experiments with the types of situations encountered in the storage of transuraniccontaminated solid wastes. At present, it is not possible to make realistic predictions for the actual rates of gas production in these materials by the above mechanisms. In the case of radiolysis, for example, the rate of production of various gases will depend not only upon the amount of transuranic contaminant present, but also upon such factors as the "exact composition of different wastes present, the manner in which the waste matrix and transuranic contaminant are intermixed, and even the packing density of the antained waste. Pyrolysis and other decomposition mechanisms will be dependent upon temperature and chemical contaminants present.

For these reasons, appropriate measures nesd to be taken only if a problem 
materializes. In fact, sufficient quantities of flammable gases to invoke this requirement may not be produced in the 20 -year period. Thus, a requirement that the storage facility be ventilated, based upon the mere possibility of a future problem, way be unwarranted as well as unnecessarily costly. A provision in waste package specifications for containment of all gases produced may also be unreasonable in light of the many unknown factors. However, in order to prevent any violent propagation of fire, a limit of 108 of any explosive gas mixture is suggested as the point at which some form of corrective action mist be taken. Since many of the gases considered have very low explosive limits, the $10 \%$ value might be expected to provide a sıfficient safety margin to permit safety measures to be taken. Provision for monitoring the storage facilities for such gases is called for as part of these guidelines.

This guideline for required corrective action is considered adequate to allow both a decision for and an implementation of the necessary action before a real problem develops. Gases, if generated, may tend to collect in the storage area in pockets containing locally higher concentrations. Again, the limit of $10 \%$ of the explosive mixture should be sufficiently low that even if such localized pockets are formed, they will not contain a flammable gas mixture.

\section{Storage Facility Operation \\ 1. Operationa1 Procedures. \\ Guideline}

A11 operations of a storage facility should be covered by an approved and documented procedure.

Written operating procedures are already required at AEC facilities. A11 operations carried out at the waste storage facility must be covered by a documented and approved standard procedure. Areas to be covered by such procedures at a storage facility should include, but should not be inited to, storage facility monitoring, package inspection, waste handling, acceptance of packaged waste, and emergency procedures covering the occurrence of fires or other potential untoward events. The operating procedures should also include docunentation of the site definition of normal retrievable waste. Such a definition can be used to deternine special cases requiring additional safety analyses before storage. Procedures to be used should be approved through the standard managerial channels of the operating contractor.

\section{Monitoring.}

\section{Guideline}

Provision shall be made for monitoring of the storage area for radioactive release and other parameters appropriate to the safety of the storage area.

Monitoring of the storage environment will be useful in determining conditions existing within the storage facility. Different forms of monitoring can define environmental storage conditions that may cause package corrosion, detect situations that could pose problems to retrieval operations, and help maintain safety at the storage site. Maintenance of records on the monitoring data and periodic comparison of the results to determine any observable trends are advised. In addition, procedures should be established to correct any unsatisfactory condition detected by the monitoring program. Such corrective actions may include the need for visual inspection of the packages to determine the extent of any damage. Some items for which monitoring in the storage facility would be particularly appropriate are described below.

a. Airborne Contamination

In the event of a major breach of waste packages, monitoring of the air in a storage facility for airborne contamination may detect the condition. In a ventilated storage facility, monitoring of the exhaust air should be carried out in 
a manner to ensure that airborne contamination levels are as low as practicable. In a completely closed facility, air monitoring need be carried out only at periodic intervals, or whenever personnel cust enter the facility for any purpose.

Extensive continuous monitoring of a storage facility for airborne radioactivity need not be required because information obtained by this technique would be of a limited nature anyway. Thus, minor losses of package integrity would probably not be detectable and by themselves would pose little threat. On the other hand, a major loss of package integrity would probably be detected by the limited use of properly situated monitoring equipment (for example, at a ventilation port).

Along these same lines, some monitoring for airborne radioactivity outside of the storage facility is suggested to provide routine assurance that the environmental concentrations of airborne contamination meet the AEC guidelines. At an AEC installation such monitoring would be a normal fert of the environmental monitoring program.

b. External Penetrating Radiation

Whenever a storage facility is entered or waste packages handled, normal monitoring procedures should be followed for the safety of the personnel involved. During the period of interim starage, levels of penetrating radiations from certain stored transuranic wastes may actually increase due to the growth of $241_{A m}$ into the isotopic mixture.

c. Air Analysis for Combustible and Corrosive Gases

The possibilities of producing combustible and/or corrosive gases from several waste decomposition processes has been discussed. In the case where the storage facility is well ventilated (for example, a forced air system), monitoring for these gases may not be necessary. However, if the facility is to be closed off, as is presently done at the NRTS, ARHCO, ard eventually at LASL, conitoring for buildup of these gases will be essential.

At the least, periodic monitoring of a closed storage facility will be necessary, with gas sanples being removed from the storage emvironnent and analyzed. Potentially hazardows gases, if produced in sufficient quantities to escape individual waste packages, nay build up concentration in the storage area over long periods of time, thus necessitating only periodic monitoring. Another characteristic that may be associated with such gas production in the facility is the possible tendency of gases to form in pockets rather than to $n i x$ homogeneously throughout the facility.

d. Smoke Detection

Assuaing guidelines relating to the presence of and use of combustible materials in the storage facility are adequately followed, there should be reasonable assurance that a fire will not occur in the storage area. Wevertheless, in any situation where combustibles are present in the facility, consideration should be given to the use of smoke monitoring as another neans of continued checking on the storage environment. As with the use of equipment for monitoring airborne radioactivity, smoke monitoring equipment should be used in such a way that fire could be detected in areas where combustibles are present.

e. Temperature and Humidity

The rate at which external sources will cause deterioration of the waste packages will depend on the temperature and humidity in the storage environment, as well as on the type of packaging material and any external protective coating that may be present. Should external package corrosion be found to be progressing at an excessive rate under one set of environmental conditions, some definition of those conditions will be of value in effecting necessary changes. If a storage facility is designed to provide direct control of temperature and humidity conditions, monitoring of these conditions will be necessary to maintain control throughout 
the facility.

f. Collection and Analysis of Runoff Water

Any runoff water from a storage facility should be collected and analyzed, because the presence of free water indicates a potential problem and is an important subject for monitoring. Thus the rate of package degradation could be increased if groundwater entered the facility or if free water originated from the actual stored wastes when package containment had already been lost (a remote possibility). At any rate, all free water leaving a storage facility should be collected and monitored before it is released to the outside in order to ensure that contamination is not allowed to escape.

\section{Acceptance of Packages}

\section{Guideline}

Acceptance standards for packages to be stored shall be defined. Such standards should include, but not be linited to, the types of packages to be accepted and the information to be supplied. The final decision as to the acceptance of any waste package should rest with the operator of the storage area.

Once the waste packages have been accepted at the storage facility, it is the responsibility of the facility operator to maintain the safe handling and retrievability of the packages. The methods of handling and storage of the wastes should be organized to provide compliance with AEC standards and with these guidelines. In order to ensure adequate functioning of the storage racility, the operator must be able to specify which packages will be accepted.

Procedures for arranging the waste packages, unloading them from the transport vehicles, and stacking them in the prescribed array will be established by the facility operator. The stacking arrangement, types of handling equipment, and environment prevailing in the storage facility will contribute to the requirements placed on package acceptability. Maintenance of the retrievability of the packages may require linitation of the acceptable weight of amy contaimer to prevent possible damage to the lower packages in a stack. In additiom, it will be mecessary to exclude packages sufficiently damaged to hinder the safe storage of the wastes. For these reasons, the facility operato nust be able to set the acceptance standards of waste packages at the storage site.

However, decisions concerning the types of packages should not be nade arbitrarily by the facility operator. Consideration should also be given to the procedures and needs of the waste generator. Operatorgenerator connunication should result in flexibility at each end of the waste handling process so that workable compromises between existing storage conditions and available package types can be reached.

In addition, the operator must have sone control over the infornation supplied by the waste generator. Al though certain inforvation on each package is required by these guidelipes, the operator may feel that supplecentary data are necessary to ensure the safe operation of the facility. J. Records and Package Labeling

\section{Guideline}

Each package of waste shall be labe1ed in such a manner that the package can be identified from a separate set of records. Such labels shall be designed to be legible after 20 years. Minimum information kept in the records shall be as follows:

1. General Information
a. Package Identification
b. Date of Packaging
c. Source of Waste
d. Location of Package in Storage
e. External Radiation Level (neutron-gamma)

\section{Package Contents}

a. Description of Haste Matrix
b. Hazardous Chemical Content 
c. Combustible/Noncombustible Designation

d. Estimated Weight and Nolume of Contents

e. Transuranic Element Content

3. Description of Package and Packaging Material

The AEC plan for management of radioactive waste requires the labeling of waste packages and record-keeping on wastes disposed of. 5 Such informational requirements can serve several purposes. During the period of storage of waste materials and at the time of their retrieval, it will be important to be able to identify them. If, for exarple, certain types of packages are found to be failing and repackaging or closer surveillance becomes necessary, it should be possible to identify all like packages and their location in storage. Actions to be taken at the time of retrieval have not been defined and probably will not be until further details on the final repository concept and requirements are available. It is possible that further treatment to immobilize the wasces will be used at this time or that the standards set for the permanent repository will require recovery of at least a portion of the contained transuranic elements. Actions to implement such a recovery process will require information on the types and quantities of materials in storage, as well as the ability to locate those wastes that require each type of handling or treatment. Thus, it appears that some system of providing such information must be rital part of the overall storage concept.

Current record-keeping and packagelabeling practices vary among the different storage sites. A system in which the coordinates of the burial site are recorded for each shipment, along with the place and date of origin of the waste materials, has been used in the burial of nonretrievable wastes at Los Alamos. This system has been useful in allowing recovery of specific shipeents in which valuable material has been inadvertentIy included in the waste package. I daho Falls is setting up a compre hensive record systen in which all available information on each package of retrievable waste is stored in a computer and is coded against the label on the package.

Several different methods could be used to inglecent this information system. For exanple, use of indiridual storage areas for each waste category and each packaging type would obviate the need for separate records or even for narking individual packages, since the source of the waste could be identified by its location in the storage area. However, this would be expensive; and puch of the information listed above, such as the transuranic content of the package, nould not be arailable. Similarly, a systea in which the waste category and type of packaging are designated by a coding systed involving the shape, size, and color of the package nould elininate the need for individual package records; but the difficulty of providing a large number of separate packages and packaging materials seems to override the advantages. Thus, a separate computerized record of each package, coded to the package by an identifying label containing a package identification number, appears to be the most desirable system. For a small operation, the records might be kept manual1y; but a computerized systen would allow easier access to the data at the time of retrieval and would permit detailed planning of the retrieval operation or any additional treatment required.

Information areas requiring further clarification are discussed below:

1. Location of Package in Storage At the time of package retrieval, operations will be greatly facilitated if the locations of packages of a given category are known. Idea11y, one might visualize a storage facility where the individual categories of waste are stored in separate areas so that all waste of one type can be 
easily located and moved. However, such a program may be difficult to execute because of the cost and the differences in waste category definition which occur between sites and with time at the individual sites. This means that some sorting of waste materials may be required at the time of retrieval if different treatments or permanent repository criteria are applied to different categories of waste.

\section{Description of Waste Matrix}

If waste treatment is to be carried out at some future time, data concernimg the exact materials and quantities of materials in each package will be required. This information would permit segregation of the packages by contents and allow design of the treatment processes to deal with the specific materials. If the material is to be transferred directly to a permanent repository without treatment, only general information, such as waste type, may be needed. It must be assumed at this time that future treatment is a possibility and that information on package contents must be kept in adequate detail to permit planning for this contingency.

The question of detailed knowledge of the contents immediately arises. Some materials, such as the liquid waste treatment sludges, can be well characterized when the process and the uniformity of the resulting product are known. However, in this situation detailed definitions of the terms used at different AEC sites become necessary. The degree of knowledge of exact package contents may vary from one site to the next, depending upon other needs which may control segregation and sorting. At Rocky Flats, the room and process-generated waste is sorted into a large number of categories of defined materials in order to permit better measurements of the transuranic element content of the packages. At other locations such extensive sorting is currently not done. Moreover, there appears to be no real need at the present time to require detailed sorting for the sole purpose of the 20-year storage. However, if such sorting is done for any purpose, each of the defined waste categories should be retained as an identified waste type in order to simplify later treatment. Each waste-generating site should establish definitions of the individual waste categories placed in retrievable storage and should provide for appropriate identification of packages according to these categories. Further, to provide for changes in character of the work and/or the processes used, these definitions should be updated at least annually (or whenever there is a sigmificant change in a waste stream). For urique types of wastes for which a defined waste category has not been established, the actual contents of the package should be 1 isted in the record.

3. Conbustible/Nonconbustible Designation

At the tine of retrieval, treatment may be possible for conbustible mastes. For this reason, a designation of combustible or nonconbustible naterial will be valuable in providing an initial identification of packages containing conbustibles. These naterials can then be more easily separated from all other waste forms. Any later separation by specific waste material can be made using the waste definition supplied for the record.

4. Estimated keight and volume of Contents

At Rocky Flats, a minimum quantity of waste per package is specified; and any package containing iess than this quantity is returned to the originator. This concept appears to be workable and would serve to minimize the storage space required for the wastes.

The information on the quantity of waste in the package will be useful in the scheduling of retrieval and possible treatment operations. In addition, the cumulative information will provide a better indication of the overall performance of the waste management system and the potential 
impact of possible changes in processes or waste handling. Therefore, it is recomended that weights and volumes of the packaged waste materials become a part of the record.

\section{Transuranic Element Content}

At all locations, some method of assay of the waste packages for the content of transuranic elements is used. Currently, the sensitivities that are attainable vary with package size and contents and are we11 above the $10-\mathrm{nCi} / \mathrm{g}$ level used to define retrievable wastes. Thus, packages bearing no data on the quantity of transuranic content are going into retrievable storage on the basis of an administrative decision that they might be contaminated above the retrievable limit. However, information relating to the package measurement at the time of shipment should be preserved in the records for that package. At a minimum, this will permit ready identification of those packages that have higher transuranic element contents so that decisions on possible recovery of transuranics to some minimum level can be made if required. Current developmental work indicates a possibility of assaying to the $10-n C i / g$ level in low-density wastes packaged in cardboard boxes. Such a measurement, made before the waste is placed into its actual storage container, may prove to be valuable for obtaining actual levels of contamination for the purposes of inventory and retrieval.

Frequently, additional information on the isotopic composition of the transuranic element mixture in the package can be obtained from this measurement or from other sources (such as the area from which the package originates and the types of materials handled in this area). Such information is also of value in estimating radiation dose rates or other hazards and should be preserved by the same system. Whenever possible, the actual transuranic element isotopic analysis should be provided, and concepts such as "gross alpha" or "plutonium-239 equivalent" should be discouraged.
6. Description of Package and Packaging Saterials

The aaterials specifications of the packages (including 1iners, gaskets, and coatings), as well as descriptions of closure and sealing gethods, will be required in the planning and execution of efficient retrieval operations. In addition, if experience indicates that a particular type of packaging with a given type of waste category is suffering an abnormal failure rate, such data will be valuable not only in the identification and solution of the prob1ew but also in plans for possible repackaging operations should they become necessary.

\section{ACKNONLEDGMENTS}

The guidelines for the interim storage of solid transuranic wastes were derived in the Health Division of the Los Alamos Scientific Laboratory, and the work was supported by the USAEC'S Division of haste Management and Transportation. This work was carried out in the Waste Management Section of LASL's Group H-8, Environnental Studies, under the direction of L. J. Johnson (Group Leader) and J. A. Mohrbacher (Special Consultant). Many indiriduals throughout the Laboratory have been involved in the derivation of these guidelines. Principal authors include $E$. B. Fowler $(H-7)$, J. K. Healy (H-Division Office), D. E. McCurdy (H-8), R. Mulkin (CMB-11), K. A. Pashman $(\mathrm{H}-8), J$. L. Warren $(\mathrm{H}-8)$, and $\mathrm{M}$. L. Wheeler $(\mathrm{H}-\mathrm{B})$.

The authors wish to acknowledge the guidance and technical review offered by the Division of Waste Management and Transportation and by other AEC administrative and contractor personnel. Review coments were received from the Division of Operational Safety, the Division of Production and Materials Management, Oak Ridge Operations Office and the Oak Ridge National Laboratory, Savannah River Operations office, Idaho Operations Office, Richland 
Operations office and contractors, Albuguerque operations office, Dayton Area office

and Mound iaboratory, and Rocky Fiats Area office.

\section{REFERENCES}

1. E. B. Fowler et a1., "Trarsuranic haste Research and Develofment Progran, " Los Alamos Scient ific Laboratory report LA-5281-MS (May 1973).

2. P. A. Patton and J. W. Limdsay, "ID-

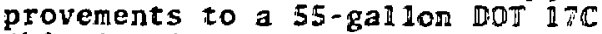
Shipping Container for Alpha-Eaiting Transuranium Waste," Rocky Flats report CRDL 950703-001 (Decenber 1972).

3. "Specification of Procurement of 55Gallon Drums for Storage of Radioactive Materials," Atlantic Richfield ranford Company report His -8828 (August 1972 ).

4. J. W. Lindsaj and $k$. E. Domning, "Inprovements to a Plyood Container issed for Shipping Alpha-Enitting Transuranium Wastes," Rocky Flats report CRDL 950612-001 (Apri1 1972).

5. "Plan for the Management of AEC-Generated Radioactive Waste," $U$. S. Atoric Energy Commission report NASH-1202(73) (July 1973).
6. F. E. Adcock, "ARMX-600 Railcars for Radioact ive haste Shipments." Rocky Elats report RFP-1411 (January 1970).

7. E. P. McDonald and J. R. Griffin, "Docucentation of DOT-SP-5948 for ATMX-500 and ATMX-600 Railcar Packaging," Mound Laboratory report MLM-1912 (April 1973).

8. R. A. Kenmedy, "Design Criteria Transuranic Dry Maste Burial Containers," Atlantic Richfield Hanford Company report ARE-2239 (Karch 1972).

9. E. Wi. Godbee, "Spontaneous Cabustion, Oxidation, and Pyrolysis of Combustibie Solid hiastes Containing Transuranium Elements in Combustible ard Noncombustible Contaimers," Oak Ridge National Laboratory report oRAL-4768 (May 1972).

B(10. 29. D. Keller, Conpiler, "Geologic Studies and Material Properties Investigations of Mesita de Los Alamos," Los Alaros Seientific Laboratory report LA-3728 (Noverber 1968).

11. E. B. Fowler, Compiler, "Transuranic hiaste Repository Studies,"Los Alamos Scientific Laboratcry report LA-5127-MS, Vo1. I (Becerber 1972).

12. C. B. Anphlett, Treatment and Disposal of Radioactive hastes (Pergamon Press, Sew York, 1961), p. 125 . 
APDERIIX A

IMMEDIATE ACTION DIKECTIVE 0511-21

Form AEC-333

(7-81)
Publisbed in advenee ol incorporatics in AEC kieral C5II

File ond minin in sicurel vaul axperseded

UKCTED STATES ATOUCC EHERGY COUUSSSON AEC LAAUAL

\section{IMMEDIATE ACTION DIRECTIVE}

IND No. 0.511-21

DATE: Harch 20, 1970

SUBJECT: POLICY STATELENT REAAROHYG SOLW WASTE EURIAI

This Insediate Action Directive (IAD) implewents the recowondations of the Task Force ca AEC Operational Radioactive Vaste lanogerenc on costing, segregation, and recrievibility of waste. (Reference $A$ Gio December 2, 1969, cerozandur to kanagers of AI, $I D, O R, P R$, and SP) This IAD applies to burials of all solid vaste atter April 30,1970 , and reilicets the field coments, which are sumarized belos, on the rask force repuri:

1. There are no objections to the apparent intent of the pollcies; and at present they are being followed, or could be followed.

2. Clear definitions and elariflcations as to intent are required for a number of the teras used.

3. Hore time 1 s needed to put the pollcies into effect fully.

4. Io some cases the costs may be considerable.

It is recognized that specific definitions would be helpful in these areas, and they will be fortheoning after addisional review and evaluation are completed by the Task Force and particularly its hozking Group on Sorting.

Heads of headquarters Divisions ad Offices and Managers of Field Offices ste resporsible for assuring that:

1. For AEC operational situatfons, intersite burlel charges Include full cost, exclisive of land, depreciation, added factor, and perpetuai care costs. For purposes 
of couparative cost evaluations of solld vaste burial (or interín storage) versus additional processing for volume reduetions ete., all costs are Ineluded; e.z.. depreciation of facilities, cost of Iaod, and preseat worth of perpetuni care costs.

2. Wastes ulth known or detectable contamination of transuraniue nuelides ore segregated froe other types of vastes by the vaste generator and kept segregated in the solid vaste burlal ground. The most sensitive and reliable metbods available for detection are used for scgregation.

MOTE: Detection 1inlts of equipsent ard being used for routine checking of plutonium-containing vaste packages is approxinntely 500 aillfgrans per cubic foot for a s-cubic foot package. Tiew Instrumentation now being tested is expected to reduce this detection Iinit by at least one order of mannitude. The application of tils oolicy uill be refined by the Working Group on Sorting as wore ir tormation is obtalined.

3. Wastes vith known or detectoble coniajination of transuraniun nuclides are packaged ard buried in surh a fashion that they can be readily retrievable as contanination-free peckages within ad interio period of 20 years; beyond that period retrievability abould continue to be possible. Wastes zeceived by - burial ground operotor, which are rot suicably packaged for retrievability, will be so packaged by that operacor with such packaging and handing costs charged to the sbipper.

Those offices which cannot comply whth the above policies shall request an exception, in writing, which states the reasons for noncompliance and Iodicating the date on which compliance can be effected. Requests for exceptions shall be directed to the saso.

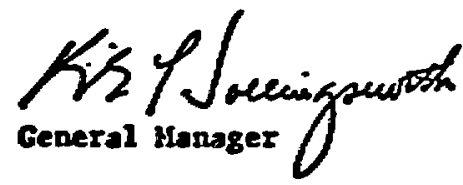


APPENDIX B

AEC MANUAL CHAPTER OSII

\section{US. ATOMIC ENERGY CORMISSION AEC MANUAL}

Volume: Coco General Administration

AEC OSIT.01

Par : 0500 Health and Safety

WMT

Chapter 0511 RADIOACTIVE WASTE MANAGEHEMT

\subsection{POLICY}

It is the policy of the AEC so manage radioactive waste in such a mansex as to minimize the jadiation exposure and associated risk to man and his environment over the lifetime of the ndionuclides.

\section{OS11-02 OQUECTIYE}

To assure safe long-term management of at sadionetive waste generated by AEC operations and of that radiosctive wasie whish is delivered to the AEC by licensed operations as sequired by regulations.

\section{O511-03 RESPONSIBLITIES AND AUTHORITIES}

031 The General Manager approves the AEC radioactive wisste management plan submitted by the Division of Waste Management and Transportation (UAIT) and determines cumpatioility of field office waste management plans with the AEC plan if

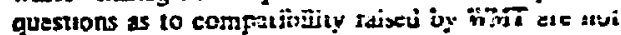
resolved by the Assisiant Generai Managers concerned.

032 The Director, Divsion of Waste Manze-ment and Tnensporntion:

a. is responsible for progran direction and fsctl control of the long-term management of high-level radioactive wastes at AEC facilities.

b. is responsible for program direction and fiecal control of all near-surface radioactive solid waste burial grounds at AEC facilities, and of engineered storage vauls at AEC facilities for interin storage of solid radioactive wastes from licensed actuvities.

c. is responsible for program direction and fecal control of operations of Federal sepositories for the disposal or long-term storage of radioactive wastes, to include: developing, performing stuaies for, iesigning, constructing, demonstrating, and obtaining necessary extermal reviews and approvals. d. coordinates the development and ansial apdatiog of an overall olan for the menazemest of radioastive waste frori $A E C$ operntions.

c. olls for freld offere waste masizement plans, reviess them with advice of program dirisions, and determines their compatibitity with the orerzil plas

f. exercises overall cogrizance, coordination. and review of waste ratasgement activities. ineluding the degree of progress in meatitis schedules and objecuives, to assure compliance with AEC policies and requirements; coordisates with appropriate prosem divisions to assure that lield oirice wate mangement plannirg and butgeting re consistent with the AEC overall plan.

5. develops, recommends, and promulgotes policies. zuides, and requirements for treatment and storage of liguid, solid. ano caseous wastes at $A E C$ iacjilies. inciudirs the definition of categories of waste: assists the Division of Operational Safery in the derelopanent of safery policies. guides. standands, and requisemenis for the reiease of radioactive efMuents to the envircnmert.

h. determines or approves criteria and specifictions, including those relating to paciaging and transport, for wastes which are to be stored in near-surface lond burial grounds or engineered storage vaults at AEC facilities, or are to be stored in Federal radioactive waste repositories.

i. preperes in cooperation with appropriate field offices and contzactor staff. emvironmental assessments and statements for major AEC waste management faciitites. in accordance with IAD-0510-29.

j. maintains: (1) central records of the capabilities and capacities of AEC facilities and Federal repositories for acceping. processing, storing, buryirs, and disposing of radioactive waste; and (2) central inventcries of radioactive waste being stored, buried. or disposed of at AEC facitities and Federai repositories.

k. provides program direction and fiscal control of a research and development grogram for

Approved: Sepienber 19.1977 
(1) techniques for long-term storage or disposal of commercial and AEC hugh-level waste; (2) compacion, incinerstion, or other improvements in handling praclices for contaminated solid waste; and (3) improsements in air cleanug or liquid effuent treatment.

1 develops and defends budget estimales for its waste maragement responsibzities and activities, including facility rez̧wiremenis, and exercises fiseal conirol over such activities; provides stafi assistanee to oither divisions in the budget submissions of waste management items for which they are Jesponsible.

m. provides advice on applicability or interpretation of the proissions of this chapter and approves exceptions. hhere warranted, coordinating these actioss with ippropriate Headquarters disisions.

n. sponsors and coordinates lesting and development of improved products and systems (such as High Efrjeiency Particulate Air Fiters) for redueing to the lowest economically and technically practiea' Jevel radioactive material releases to the environment.

D. With regasd in the above assigned aesponsibilities, acts as the General Manager's staff liaison and point of contact with the Orfice of Regulation and with other Federal, state, or local groups witin regard to activities concerning (1) AEC-generated wastes and (2) commercially generated wastes to be delivered to the AEC as required by regulations. Sofety:

033 The Director, Division of Opentiona

a. develops, recommends, and promulgates policy, standards, and requirements relevant to (1) the protection of man and the envizonment from radiation or contamination, and (2) safety of syste tis and system components used for controlling radioactive material discharge to the environment.

b. exercises cverall surveillance, evalua tion, and appraisal of AEC site effluent and environmental monitoring programs 10 assure compliance with AEC sofety standards and policy selating to protection of man and his environment in accordance with AECM 0513. and coordinates sush monitoring programs with comparable programs of other agencies. c. in cooperation with BRT, evalustes radicactive saste management programs to assure that the AEC policy of controlling the release of radieactrie materials to the lowest levels ${ }^{2}$ technically and economically practical is being implemented.

1. apprises the safety 2 spects of field office waste managmen programs and activities.

c. reviews waste moviagement plans in relation to their impant on man and the environment and recommends any appropriate modifiations to the Director, Division of Waste Banazement and Transportation.

f. coondimates with appropriate directors of program divisions prior to establishing policy standands which may have a programmatic impaet.

034 Directors of Program Divisions. Beadquarters: ${ }^{3}$

2. consistent witir programmatic responsibitities and the provisions of sections 032 abore and 044 below, provide direction of operations Ervolvisg radioactive waste zenerated in their programs.

b. Within progrenmatic responsibilitues, may provife direction and guidance consistent with appendix part II for the prepazation of waste managenert pians to ve jutbmia: :a b; fieid office managers under 038 (c).

c. reviex waste manszemedt pians submitted by field office managers relative to eacin site at which they have programmatic responsibilities. including retated comments of other program divisions which inave activitios at those same sites. and consult with the Director, WAIT, concerning his seview funetion cescrited in 032(e).

d a requested by the Director. WMIT, seview inquiries on the applicability or interpretation of the provisions of this chapier and requests for exemprions.

e. consult with the Director, OS, in matters relating to policy, standards, and requirements relesart to the protection of man and the envirosrnent from radiation or contamination

035 The Director, Division of Naval Reators, assumes the same responsibdities as managers of field offices for its respective program activities.

036 The Director, Office of Information Service, assumes responsibilities for waste generated in connection with nuclear exhibits not under direction of any field office manager.

Approved: September 19, 1973 
037 The Director, Division of Construction:

a. develops or approves in conjunction with WMT, and other concerned Headquarters divisions, design criteria for faclities to be constructed or modified for the purpose of processing or storing radicactive wastes or of controlling the release of radibactive wastes to the environment.

b. Jeviews waste management plans relative to their planned construction aetivities and advises the Director, Division of Haste Mangemeat and Transportation, on the estimated costs and schedulies and conformance with design criteriz.

\section{Managers of Field Offices:}

2 assure that the relevant criterin in 044, below, are followed in developing practices for routine and emergency operations at AEC installations under their jurisdictions and that current practices, where ofirering, tre revised to comply with the criteria

b. refer questions as to applicability, interpetetinn. or exemption from the criteria (see 044, below) to the Disector, Division of Waste Managment and Transportation, through the appropriate program divisions.

c. prepare and submil to WMT, with copies to the appropriate program divisions, angually updated waste management plans for their sites, following the general guidance in appendix 0511, part II.

d. maintain suitable approval control over key waste managment decisions of operating contrators, such as the establishment or major modification of:

(1) operating limits for quantities or concentrations of radipacuive materials released to the environment.

(2) release locations and timing of releases.

(3) methods of treatment of ef 'Tuents to minimize release of radioactive materials.

(4) methods of conversion of high-level liquid waste for interim storage or disposal.

(5) process flowsheets, to the extent that they determine the quality or quantity of wastes.

(6) methods of interim storage of solid wastes.

e. assure that for AEC operational situations, calculations related to burial/storage operntions include full cost, exelusive of land. depreciation, added factor, ant perpetul care costs. For purposes of comparative coss evaluations of solid waste buriv or storge with and without additional prosessing for rolume reduction, all cosis are included, e.g- depreciation of facilities, cost of lind, and present worh of perpetual care costs.

f. mximrain records of madiactive waste stored or buried at their sites.

- cocfuct a progam of annual appraisals of eoctractor mdiosetive waste management ectinities.

\section{DSTIOA BastC REQUIREMERTS}

041 Apptiebitity. This elupter applies to divisions and offices, Headquarters, field of fices, and contractors who operate AEC-owned or -controlled facilities and whose contracts contain the Standard Safety. Health, and Fire Protection Clause (see AECPR 9-7.5006-47).

042 Corenge. This chapter and its appendix specify the responsibijities, requirements. and proceduces wicili atoll govern the managernent of radicaclive waste.

043 Appendix 0511. Appendix 0S11 contains definitions (part 1) and guidunee (part II) for use in implementing the polisies and tesponsibilities of this chapter. The detail of the appendix is not to be 1akea as all-inclusive nor should it preempt the use of good judgment by knowiledgeable field office and contretot staff in the development of safe pracices and controis in the managenent of radioactive waste.

OA Openting Criteril. To assure an effective progam for the management of majoactive waste, the following criteria shall be observed:

2. Ceneri

(1) Field offices and their contractors shall conduct their operations and dispose of and store radioactive waste in such a maser as to assure that present and future radiation expostures to individuals and population goups will be at the lowest lerels technically and economically practical not exceedirg limits established in AECM O524 appendix parts I and $n$.

(2) Continuing efforts shall be made to develop and use improved technolozy for teducing the radicactivity releases to 
the lowest technically and economieally practical level.

(3) High-level liguid radicactive waste shall not be inansported offsite.

(4) The extent and degree of radioactive conlamination of land by AEC raste management activities shall be minimized.

b. High-Lerel Radioactive Haste

(1) High-level liquid wastes thall be converted to suitable physied and chemial forms and confined in a manner which shail proside high ssurance of isolation from maris environment with minimal seliance on perpetual mainienance and surveillance by man under conditions of credible seologic, seismic, and other naturaily cecuring events.

(2) High-level liquid radicactive wastes may be initially stored in carefully eagineered systems equipped with a jequate provision for leak detection ay d control. Tanks and transier systems shil be designed to resst credibie inte:wal and external forces. Tecinnulogy thall be developed and employed as coon as practical to reduce the volume and mobility of the ligh-level liquid wastes placed in initial storape facilities.

(3) High-level liquid wastes in init:al storage and high-level wastes in long-term storage, or in pilot plant facilities shall. in each case, be contained and emplased so as to be retrievable for removal and transfer elsewhere. The method of sorage and the physial and chemial forms of the stored waste shall be predicated on safety and nor on possible retrieval for recovery of fission products for beneficial uses.

(4) The mdiosctivity and the chemical and physical characteristics of all high-level wastes in initial, long-tern, $\alpha$ pilot plant storage shall be determined for each condition of storage.

(S) Spare tanks shall be maintained providing wolume in excess of initial storage requirements for high-level liquid wastes. Each tank farm holding hishtheat liquid waste shall have arailable, in tanks empty except for a residual heel, space equibalent to the largest volume of such wastes stured in any one tank. Each tank farm holding low-heat liguid waste shall have rrailable inserve storage capacity to acoommodate the contents of the largest tank in the system. Where interconnected tank farms are sufficiently close that the times required to transfer tark contents between farms are simitar to the times required to transfer tani contents within a farm, ouh interconnected tank fams may be considered as a single tank farm for pupoces of the above requirements.

c Other Linuid Radionctive Waste

(1) Liquid radioactive waste not meeting the definition of "high-level waste" shal be conrerted into two fractions, one corsirtiog of liquids which an be disetarged to the environment purstant to AECM 0524 (i.e., persons in uncontrolled areas will not be exposed 10 concentmitions in excess of those prescribed in rable II, annex A. appendix 0524) and the other consisting of either: (3) hightlevel liquid waste,

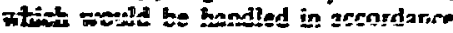
with the policies of $b$.. above: or (b) olid waste which would be handled in sceordance winh the pulicies in $d$. below.

(2) As soon as techniclly and economically practical, the use of naturalsoit columis (such as cribs, seepage ponds, ari similu facilities) for liquid stresms that exceed extablished standards for release of radicactivity to uneontrolled areas thall be reptzeed with other treatment grtems. It should be recogniced that Equid which mats establislied standards and is released to soil coilumns still may reaslt in a buildup (at a slower rate) of mdionctivity in the soil column. Tr: is, it would be astrantageous to desi/g soil column structures so either the soil can be retrieved and relocated or the points of release are separated to the extent that the buildup of radioartivity in the soi column will not exceed an acceptable level.

(3) Adequate diversion stems shall be provided to assure that normally releasable strearmi, which, as a consequence of accident er operational upses, exceed es'ablished standards (cited in AECM C524) for releases to urconrolled areis, are automatically

Approved: September 19. 1973 
detected and diverted to controlled holding areas and are rerycled or processed io yisld a releasoble stream.

d. Radioactive Solid Haste Other Than That Genersied by Solidifiction of Bigh-level Liquid Waste

(1) Teclinical and administrative efferts shall be directed toward a manked reduction of (a) the gyoss volume of solid waste generated in AEC operations and (b) the amount of radioserixity in such waste.

(2) Volume-seduction technology, such as compuction and inciseration, shall be adapted for use with radioactive solid waste and placed in operation wherever practial.

(3) Except as dictated by (4), below. solid radioactive waste may be stored in conventional burial grounds appsoved by the $A E C$.

(4) Solid waste generated at AEC sites and containing significant U-233 os transuranium nuslide contamination shall be stored at AEC sites, segregated from other radiouctively contaminated wiiv waiti and with combuctihls and noncombustible transuragiumcontaminated waste packaged xparately. The packiging and storage conditions shall be such that the packages can be readily retrieved in an intact, contamination-free condition for 20 years. The packages shall be suitably labeled so the waste they contain can be identified by cross-seference to permanent records.

c. Airborne Radioactive Effuents. Gascous and other airborne mdionstive eflluents shall be controlled at the lowest level below the limits of AECM 0524 consistent with the state of the technology and good economic practices.

f. Other. Radioactive waste generated by undergtound nucleat tests, and remaining underground sholl be considered as a special case.
045 References

1. AECD1 26D1. "Physion Protection of Chasified Malter and Information." for additional protection required for chassified radicactrise waste.

b. AECIA OS10. Prevention, Control, and Abrtement of Air and Wiater Pollution:"

c. AECI 0S13. "Emuent and Ervironmental Moniloring and Reporting."

d. AECY 0S24, "Standards for Radiation Protertion."

e. AECA 0S29, "Safety Standards for the Packagin: of Fisole and Other Radiosctive Materials."

f. AECMI 0530, "Nudear Critieslity Safety."

- AECM1 OS44, "Planning for Emergencies in AEC Operations"

h AECIA 6201, "General Design Criteria."

i. AECH 7401, "Sofezuards Control and Management of Nuelear Blaterials."

j. WaSH-1202, "Plan for the Bianagement of AEC-Generated Radiozetive Wizstes."

$k$ AEC Property Manzement Instructions Suban 109-45.50, Excess and Surpiss Radioactively Contaminated Personal Property."

0511-05 NATIONAL̂ ENERGEROY APOLICAT?ON

In the event of a rational emergency, as defined in AECM $0601-04$, the provisions of this chapter and its appendix stall continue in effect.

In the context of the policy ratement in AECH os24-012.

Ifi the context of the poticy statement in $\mathrm{AECH}$ 0524012 .

For purposes of this chapte, proge 7 divisions are those Headquarters divisions that povide functionsl Lrection of activities which penerete radiosctive wasle. 
PART I

\section{TERMINOLOGY}

\section{A. PURPOSE}

This part provides terminology to be used in interpreting and implementing this chapter. For consistency, its use is recommended an other communications concerning radioncture waste mongement.

\section{B. USAGES}

1 Airborne Radioactive EffuentsRadioactive particulates, mists, vapors, fumes, and/or gases, contained or entrained in air effuents. (Niote: The special case of materials such as $\mathrm{Kr}-85$ removed from effuents and packaged for retention. should be described as "Compressed radioactive gases" or "Adsorbed radiosctive gases.")

2. Combustible (for purposes of AECM 051 1-044 d.(4)-Orpuic material capable of being burned, except that if the coly combustible content of a package is plastic lining or wrapping used ior conistnimsizun control purposes around incumbustitele objeets or materials, the conients of the peckage as a whole may be considered noncombustible.

3. Contamination. Fise (for purposes of AECM 0511-044 d.(4)-A condition of the outer surfaces of stored containers, as determined by appropriate swipe surveys or direet radiation instrument surveys, sufficiently free of contamination so that under standard radiation work procedures for the site in question respiratory protection will not be required during container handling.

4. Crib-An undesground framework or structure into which liquid wastes are discharged, located so that the radioactivity (other than tritum) is sorbed on the soil before the liquid reaches groundwater.

5. Disposel-The planned release of radioactive waste in a manner that precludes recovery. or its placement in a manner which is considered permanent so that recovery is not provided for. (Note: If recovery is planned. or could be provided for easily as in the case of compratiomal surface burial grounds. the term "storgge" should be used.)

6. Dirersion-As applied to nomirally uncontaminated furid streams, the capaility of zutonatically detectins excessive maficactivity and diverting the stream to a retention sstem for treatment.

7. Erfluents-Airborme and liquid streams discharged from a fecility asiter all engineered frocess waste treatment and effisent comtrols have been effectec. Releases offisite or into grouniviater and surface streams whish leave the site or go to the atmosphere from engineered systems such as starks, lagoors, retention ponds, or injection wells are to be considered Is efinuents. The term does not inelude solid waste or other waste which is contained (e.g., underground nucleas test debris). stored (e.e, in lagoons, tetention ponds. menches. terkesh. or shipped offssie.

8. Storage-Retention of radioactive waste in some type of man-made device, such as a tank of vult, in a manner permitting retrieval.

9. Long-Term Storage-The status of radioactive waste under control and surveillance, and readily retrievable, but in such a form and location that no further processing or maxipulation is considered necessary for a period of time whith is very long compared to other periods of time in the nuclear fuel cycle; an example wouid be storage in a high-quality near-suriace storage vault with an expected durability of mary decades.

10. Fedenl Repository-A Federally owned and operated facility for storage or disposal of specific types of radioactive waste from AEC sites and/or licensees.

11. Federal Reservation-As AEC sile requiring long-term contrel and sestrictions because of stored or buried waste or decommissioned facilities. 
12. High-Hat Liquid Maste-Liquid waste containing sufficient thermal enengy to require some supplemental means of cooling, such as cooling coils.

13. High-Level Liquid Waste-The aqueous waste resulting from the operntion of the fist-cycle extraction system, or equivalent concertrated wasles from subsequent extraction cycles, or equivalent wastes from a process not using solvent extraction, in a facility for processing ïrradiated reastor fuels

14. High-Level Haste-(a) high-level liquid waste, or (b) the products from solidification of high-level liquid waste, or (c) inadiared fuel elements if discarded without processing.

15. Other Liquid Waste-Liquid waste. not within the definitions of high-level liguid waste.

16. Liquid Radioactive Waste-Solutions, suspensions, and mobile sludges, contaminated with radioactive rnaterials.

17. Management (Waste)-The planning (including design and process improsement), execution, and surveillance of essential functions related to cuntrol of radioactive waste, including treatment, solidification, initial or long-term storage, and disposal.

18. Radioactive Waste-Materials of no yalue consisting of, including. of cuntaminated with radioactive material in excess of the levels or concentrations permitted in AEC Property Management Instructions for unconditional release of excess property. This includes (a) stored liquid, solid, or gaseous residues from chemical or metallurgical processing of radioactive materials: (b) discarded nems such as defective equipment and building rubble. not radioastive in themselves but contaminated with radioactive materials: and (c) discarded items containing induced radioactivity. Treated as a separate category are: (1) irradiated fuels stored for possible processing: (2) radioactive scrap stored for possible recovery of useful values: and (3) materials and equipinent stored for possible future use following decontamination.
19. Retention Basin-A watertight basin in which liquid waste is held for any one or more of the following reasons: (a) the decay of thont-lined redicactivity: (b) analysis to verify activity leveis permitsing release: (c) recycle fos treatment:(d) emporation

20. Seepse Busio-A basin in permenble earth through which liquid percolates and in win rudicactivity, except for tritium, is sabed.

21. Serting Buxin-A watertight basin designed for reparating siudges and sediments as a layer on the boltom. The water is disposed of by orerlow or solar emporation.

22. Solfd Radioactive Haste-Material that is essentially dy but may contain sorbed radionetive fluids in surficiently small amounts 20 be immobite when buried in dry soil.

23. Transurasium-Contaminated Solid Haste-Those contaminated with certain alpha-emitting radionuelides of long inlf-life and high specific radiotoxitity to greater thã 10 nangrurieslgram 110 microcuries/kilogram), suhject to the following conditions and understandings:

2. The radionuclides insluded are U-233 (with its daghter products), plutonium. and transplutonium nuclides except Pu-238 and Pu-241. (Note that Pu-238 and Pu-24! wasie should be handled as transuranium-contaminated waste when 20 indieted by Pu-239 impurities or when required by local burial criteria.)

b. The value of $10 \mathrm{nCi} / \mathrm{g}$ is derived from the upper range of concentrations of rodium-226 in the earth and is subject to modification based on long-term studies of nuclide migation in soil.

c. The activity density may be averaged over the contents of individunl shipping containers, such as 55-gallon drums, including materials added for shielding or sorption of liquids. Late discovery (for example, on recalculation of data) that an individual container is above thts level will not be considered as necessitating its retrieval provided there is reasonable assurance that the average of the container and the balance of the ssocinted containers is below the level. 
d. For typical Pu-239 waste at this activity density, it is recopnized that ancirect measuremerts or estimates and administrative controls must be used instead of difect external measurements. An example of such administrame controls is the estublishment of spesatis in-plant working areas from which typical wastes have bees eslabisised by suitable studies as being either above or below the control vaine.

e. It is recognized that under present technology certain waste, primarity bulky discarded process equipment. with transuranium content above this value may not lend themsetves to practical storage in full compliance with AECM 0511-04 d(4). However, these items should be recorded as transuranium wastes.
1. Requests for exception for applyng the $10 \mathrm{rC} / \mathrm{g}$ valiue on a package-by-packags basis, with subsuntution of in equiraleat quantity limit eppisicable to a bural facility, or requests for exemption fo: specifie short halfined transplutonum wastes, with be constdered on a case-by-cose basis, as per AECM $0511032(\mathrm{~m})$.

8. The $10 \mathrm{nCi} / 6$ value is a criterion for choosing differemt methods of handing differemt kinds of radioactive waste; it should not be confosed with a value belon' which excess malerials may be wazorditionally released, as per AEC Pioperty Management insiructions 10945.50 . 


\section{WASTE MANAGEMENT PLANS}

\section{A PUAPOSE}

This port provides guidance on the developintent of a radicactive waste management plan for each size, as required by AECM OS11-036c.

\section{B. DISCUSSION}

Existing conditions al the various facilities wall require different types and dectees of effor to meet the operating criteria of AECM OS11-044. Accordingly, the plars submitted nuder AECMS $0511-038 \mathrm{~s}$ need not be identival in degee of detad Appropriate references to suppiement or sutbstartase the information or conilusiors stated in the pian should be provided. The outiire of a waste management plan in C, below, is to be followed.

\section{FORMAT FOR THE SITE WASTE} MANAGEMENT PLANS

\section{Program Administration}

\subsection{Site}

1.2 Office Responsible

1.3 Contractors

1.4 Lead Responsibility for Site Plans

is Source of FY 1972 Finds for Haste Management

\section{Description of Waste Generating Processes}

\section{2.] Process Flowcharts}

3. Description of Waste Maragement Facilities

3.I Identification and Location of Facilities
32 Description of Haste Treatment Facilities

3.3 Description of Haste Storage Facities 3.4 Description of Efnutent Control Systeans 3.5 Site Administrative Limits on Eftuents

4. Radioattine Waste Stored

4.I Hîgh-Lerel Waste From Chemical Proeessing Operations

42 Solid Radicactive Haste Other Than Solidified illigh-Level Wate

4.3 Other Radioacturve Materials

5. Plans and Budget Projections

5.1 Interim Storage of High-Level Liquid Maste

S.1.1 Bsilestone Charts

5.12 Expected Accomplishments in FY 1972

5.1 .3 Proposed Prozam for FY 1973 5.1.4 Proposed Program for FY 1974 and Beyond

5.1.5 Five-Yeas budget Frojects ín :F' 1974 and Beyond

52 Long-Term Storage of High-Level Waste

5.3 Management of Low- and Inier. mediate-Level Liquid Wiaste

5.4 Management of Solid Waste Contaminted With Radionetivily

SS Management of Airbonne Radicactive Waste

5.5 Reapituation of Bujget Projection

Detailed instructions for site waste management plans will be forwarced periodically to field oifice managers. 


\section{APPENDIX C \\ IMMEDIATE ACTION DIRECIIVE 7401-19}

Fom AEC.J33

(7.6)
Published in advance of inenrporation in AEC Manual Appenuix $\because \leq 01-3$, File and retuin in Itanual until superseded.

UNITED ST ATES NTOMC ENERGY C.OMMSSION AEC MANUAL

\section{IMMEDIATE ACTION DIRECTIVE}

IAD NO. 7401-19

DATE: May 26, 1971

\section{SUBJECT: SCRAP MANAGEMENT PROGRAM}

\section{A. Background}

The recently submitted reports on plutonium handling and processing and on the management of oralloy inventories indlcate that excessive quantities of scrap or otherwise Inactive nutiedi matszil exist In invertories throughout the AEC compiex. In sone cases, there are inaciequacies in the manner in which this material is stored and handled.

Pursuanc to AEC 132/168, the Division of Waste and Scrap Management (WSM) was estailished by Announcement vo. 84, dated July 10,1970. The responsibilities of this Division include providing for consistent policy determinations and coordinated management of scrap nuclear faterials at AEC facilities as well as establishing more ex̄ective control over the storage and reprocessing of scrap containing special nuclear material.

\section{B. Scope and Purpose}

1. This Directive establishes a system of managenent for unirradiated scrap plutonium-239, plutonism-238, enriched uraniun and $U-233$ generated undar AEC contracts or subcontracts. Additional sarap materials may be incorporated into the system in the future. Responsibilicies of the scrap generatur are identified and a Central Scrap Managenent office (CSYO) is designated to provide uniform disposition of Pu-239, Pu-238 and ensiched uranium in scrap form. A CSMO to service $j-233$ is not establishec at this time pending a definition of the requirements and pollcles which should be instituted for this material. 
The Director, nivision of Production, the Assistant General Manager for Military Application, and the Director, Division of Snace :uclear Systems, will institute criteria and procedures for the managenent of scrap in recovery facilities under their control comparable to those exercised by the CSMO's. This will include, where appropriate, the measurement and treatment of scrap for safe handling and storage, adoption of consistent discard criteria and recovery priorities and, in consultation with WSM, seeking appropriate alternatives to local processing when scrap nuclear material cannot be recovered locally on a current basis.

2. In general, the purpose of this scrap management system will be to provide uniform management disposition of scrap nuclear materials regardless of their programmatic origin in consonance with the responsibilicy for the safe handling and safeguarding of the material and provide for the timely recovery of scrap.

3. This system supplements and implements the management responsibility and policies and procedures contained in AECM Chapter 7401 and AECM Appendix 7401, B., Part III. Appropriate amendments will be issued later.

\section{c. Defintitions as Used in This IAD}

\section{Scrap Nuclear Material}

Scrap is defined as unfradiated nuclear material that is not usable in its existing form, is mixed with other material necessitating purification to be rendered useful and which can be recovered in an economical and safe manner. Excluded, for the purpose of this IAD, are scrap nuclear materials that are considered a feed or are reclaimed on-site on a current basis as part of a production or fabrication process. Current basis means without the buildup of an excessive backlog of scrap in storage pending recovery, or the inactive storage of the material for a period greater than six months.

2. Scrap Generator is deftned as the contractor which performs work under an dEC contract which generates scrap nuclear material in the course of that work. 
3. Central Scrap Yanazement of eic: (CSMO) is defined as an AEC ficld of ice that his bean designated to implenene the scrip managenent system for a specific muterlal. The csiro will receive declaritichs of scrap from scrap generators, make deterninations of recoverabilicy as outlined in this IAb) and Issue instruetions for disposition accordingly. The following of fices are designated as isyo's:

For enriched uranium, Oak Ridge Operations Office.

For plutonium, excluding Pu-238, Richland Operations office.

For plutonium-238, Savannah River Operations office.

For U-233, the Division of Waste and Scrap Management will assist in arranging disposttion of serap in consultation with the U-233 inventory annagemert conducted at Oak Ridge laticnal Laboratory.

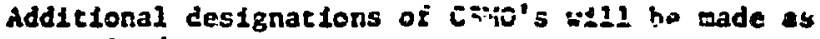
required.

D. Organization and Implementation of Scrap Managenent System

1. feneral

The scrap management system herein established is based upon the provistous of AECM Chapter 7401 and Appendix 7401, B., Part III, with certain local responsibilities assigned to the serap generator as well as the implementation, by a CSHO, of a uniform and centralized scrap management program for each type of material.

\section{Role of Scrap Generators}

a. Each scrap generator w11l be responstble for local ecrap handling and storage operations. These operaclons Include the determination of nuclear mazerial content for safeguards and assay purposes by the besc approved means, making the material safe for shipment, torage and handing by placing it in a stable form. corting into reasonably homogeneous lots and packaging and labeling the material to permit proper shipplng. otorage and handling. The materlal shall be packaged in 
noncumbustible primary contalners suitable for storage and, for those sites nec hoving processing tupatility ior the serap, in primary coneainers suitable for subsequent shiphent tithut repuckaping. Laveling of the miseriai shall permit a posisive Identifieation of the contained material, its composicion and oriçin (ref. 7401, B.. 111. 1.). The scrap benerator will aiso be responsible for Interim storage and for transporcing the serdp nuclear waterials which it geicrates to the recovery site desinnated by the CSyo or. If the material is adjudged woste. disposing of the material chrough approved wasce management procedures.

The cost of the local scrap management operations will be funded within the budgets for the programs which generace scrap. It is the responsibilicy of the Director of each program division to assure that adequate iunds are budgeted and remain available for the tirely preparation and resoval of scrup gencrated ditin his prograns to the recovery site designated by the CS:Y. The amounts of such funding will be cisclosed within ste Comission at all levels of budget ravies.

b. The serap generacting stes shall issue deciaratiens of ccrap naterial avallajle zor recovery elsewhere through the cosnlasnt A.C field oilice to the CSHO assigned responsinflity tor the particular material with copies to WSM and the program division involved. These declarathons will be issued as soon as the material is identizied as scrap but in no ease will material be scored for a pertod greater than six months ac the generating sice without arrargenents being mode tor lts disposition within the scrap minaseacnt system. In order so assure that macertal is declurec on a curcent basis and that serap generators follow through wieh disposition iastructions, each AEC fleld office will reporc semiannuaily the inventory and status of such materisls under its cognizance. The zepert will sunsarize the tocal scrap invenzory, the material detiared to the Csto for disposition, the ascerial shipped for recovery and the material disposed of as wasec luring the peried. These reports shovid be provided within four weeks of the periods closing December 31 and June 30 of each year and should be directed to the Division of Waste and Scrap Managemeat, Headquarters, the off $t$ ce of Safeguards and Macerials Management. He dquorters, and the fleadquarters pregran division ol d-distons having

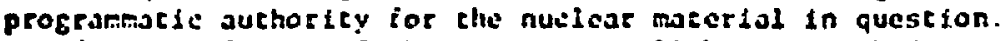
The detafled forfate of chese repores will be prescrlbed follnving a reviau of the subnissions made in resporse to the memorandum of Janusey 12, 1971, requesting a report of the current inventery of scrap and Inactive waterial. 
c. The scrap generator will include in each declaration such information as will pernit the CSMO to determine the proper disposition of the matertal in accordance with Afi policits. These are detailed in the attachment to this IAO. Ref. paragraph 2.

3. Role of Office of Safcruards and Materials Management

The Office of Safeguards and Materials Management (OSMG), In kecping with its asstgncd functions, will appraise field office manaytient of nuclear materials and audit and report quantitative data on materials including scrap.

4. Consideration nf Scrap in Forecasts of Nuclear Material Requiremencs

Divistons particlpacing in production planning and the preparation of supply schedules shall incorporate the avallability of such materials from scrap sources.

\section{5. nule of AEC Ffeld Offices}

AEC fleld offices will continue to audit and appralse contractor ferformance including compliance wth this IAD for managenent of scrap nuclear materlals. Ref. Append1x 7401, D.

6. Role of Central Scrap Management Offlces

a. The CSNO for each nuclear material will evaluate the recoverability of scrap materlals feclared to them by the scrap generating site and will issue appropriate instructions for the disposition of the material as recoverable scrap.

b. The assignnent of this "ciearinghouse" function to -designated AEC field offices and Instructions on the procedures to be followed for evaluation of serap matertals under chis systen will be made by WSM. Inttial designation of the CSMO's is indicated in paragraph C. 3. Basic procedures for the activities of the CSMO's are included in the attachment to chis IAD.

7. Role of the Divisions of Production and Military Application

These organizations will institute the procedures and adopt criterla for the managenent of scrap nuclear materlal generated In theit respective prograns which are approved by WSM and are consistent with the scope and purpose out lined in B. above. In addicion, the Divisions of Production and Military Application 
will provide operational management of scrap processing facilities at sites under their cognizance and, in consultation with ifl, fuvelep programs $t ;$ apply the capabilities of these facilities to the program of scrap recovery.

8. Role of Rivision of laste and Scrap Yanazement (WSM)

a. WSM will he responstble for supervising the program for disposition of non-02-03 plutonium and enriched uranfum scrap and contercial recovery prosessing. WSM will also develop operational plans in consultation with the cogniant pregrams divisions for the recovery of non-02-03 scrap in AEC facilities. WSM will review and approve the scrap management plans within the 02 and 03 Prograns to assure that the operation of recovery facilities and management of scrap inventories is consistent with overall AEC policies.

b. For FY 1973 and beyond, WSM will be responsible for all aspects of the management of non-02-03 plutonium and enriched urariuin scrap recovery in both coumerci.il and AEC facilities. For non-02-03 plutonium and enriched uranium scrap that is iu he recovared in AFS. factlities, WSy will develop recovery plans in consultation with the program divisions having operational responsibility for these facilities. WSH will continue to review and approve the 02-03 Program scrap management plans as noted above.

\section{E. Budgeting and Funding}

1. In FY 1971 and FY 1972, funds already budgeted under the 02 Program for scrap processing will be administered by WSM and the Division of Production. WSM and Production will jointly administer funds for non-02-03 scrap processing and Production w111 administer funds for 02 scrap processing. For FY 1973 and beyond, non-02-03 scrap management operating costs will be budgeted as a separate line ttem under the "Special Activities" account in the special nuclear materials (02) program. WSM wfll be responsible for revlewing the budget estimates for scrap storage or recovery operacing costs, research and development costs, and equipment, GPP and Ine item construction costs and for preparing and justifying the non-02-03 estimates in the "Special Activities" account for these operations in AEC facilities and consercial recovery contracts. 
2. General plant profects and capital equipment will continue to be budgeted by the prostam division having operational and contracting responsibility for scrap recovery facilitles. Spccific general plant projects and capital equipment 1tems relating to scrap management will be developed and justified by WSY and will be separately identified in internal AEC budgets and subsequently incorporated into the appropriate program division's GPP and equipment estimates to OAB. Special Ine item construction projects relating to scrap and waste management may be developed and advanced by WSM in the budget of the appropriate program division having the site respons1bllity where the project would be located.

3. The cognizant operating divisions will continue to be responsible for contracting and operating AEC scrap recovery facilities now under their jurisdiction. WSM will advise the cognizant operating division as to the amount of non-02-03 scrap recovery which should be considered in the operating plans for AEC facilities under theis control.

4. The CSMO will arrange for recovery of scrap in comerctal facilities in accordance with AEC policy, WSM program guldance and the best interests of the scrap management program.

5. See D., 2., a., above for budgeting and funaing requirezents for scrap generators.

\section{F. Other Basic Requirements}

1. To the extent feasible, fixed-price contractors of the AEC will continue to be responsible under special terms of their contract for securing commercial recovery of their scrap.

2. The operations of the CSMO's in receiving declarations and arranging the disposition of declared scrap shall be instituted as soon as possible. Scrap generators are to act tomediately to comply with their responsibilities as outlined in this IAD and issue declarations for any existing tnventories as well as required reports and forecasts by June 30,1971 . This scrap management program shall be fully implemented by FY 1973.

Any questions relating to this IAD or its fmplementation should be addressed to the Director, WSM, for resolution.

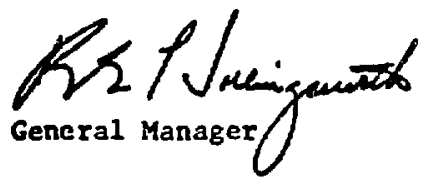

Atcachment:

Criterla and Procedures 


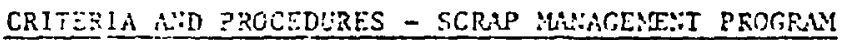

The follcine criteria and procedures describe the activity of the scrap manareient system estabiished by IAD 7401. The policies of AECN 7401 and its Appendices and other AEC Manual Chapters of the 0500 series relating to the safety of operations remain in effect and are unaltcred ty the institution of the criteria and procejures outlined hectis for inplementation of the scrap management program.

\section{Criteria}

\section{a. Safety}

Operattons such as sorting, storage, handling, transportation and processing of scrap nuclear materials shall be performed in such a manner that the potential risk of fire, criticalicy, loss, contamination or injury is minimized. Prellwinary treatments such as passivation, incineration, neutralization, decontamination or other processing which Is necessary to reduce the hazard of handling operations to acceptable levels shall be performed as part of the initial disposition of scrap waterials even though the raterial may ultimately be determined iu ve discarduble as waste. The matertal is to be sorted to provide reasonably homogeneous lots with resfect to recovery $p$ zocessing and packaged in nonconbustible containers suitable for safe storage. If material cannot be processed on-site on a current basis, the contalners are to be suftable for use as primary containers in subsequent storage, transportation and handling operations without necessitating repackaging. Packages are to be labeled in accordance with Appendix 7401, B., III, I. The label affixed to the primary container should be suffictently rugged to remain intact through nọrmal handling and storage operations. In the event labels are lost or destroyed, an Index marking should be affixed to each primary container that w111 maintain the identity of any intact container. Unnecessary combustible items are to be minimized in storage areas or facilities. It is the responsibility of the scrap generator to provide for and carry out these operations as part of the day-to-day management of scrap materials.

\section{b. Evaluation of Nuclear Marerial Content}

The nuclear material content of all scrap will be measured or otherwise determined for safeguards and accountability, to assure its safe handling and for evaluation of recoverabilfty. This determination will be performed as soon as the scrap is idencifiable regardless of whether it will be considered for recovery or for disposal as waste. It is the responsibility 
JAD No. $7401-19$

of the scrap gencrator to make this detemination including such fiedsurwent:s as are technically and economically feasible or necessney and to fnclude such data as part of the labeling of the scrap container and for the declaration of scrap for disposition.

The criteria outllned above for safery and measurement associated with scrap management are prerequisite to the aispositicu of scrap under the scrap management program and are the responsibility of the generating gite. Care should be exercised in the selection of processes and treatments to anticipate these requirements and make adequate provisions for compliance before material is committed to the process or operation.

\section{c. Retention and Recoverability of Serap Nuclear Material}

\section{(1) General}

Scrap nuclear material will be considered for recovery If it is of economic advantage to the AEC or is necessary to assure the safe disposition of the material. The option of recovery processing will be selected when it is necessary for the safe disposition of the material and contributes to meeting current requirements or requirements that are forecast for the nuclear material. Retention w1ll be based upon obtaining the maximum benefit

from the nuclear material at minimum current cost.

\section{(2) Formula}

Material will be adjudged recoverable by the CSMO when there is a requirement fur materlal and the material considered for recovery satisfies the following conceptual formulation:

$$
\text { C } \leqq I+D
$$

Where: $C$ equals all Incremental costs of recovering the material including the additional costs of packaging in a shipping container for transfer to the recovery site, handling and shipping associated with transportation to the recovery site, processing to the standard feed form, disposal of residues from the reprocessing and parkaging, handling and shipping of the recovered material to the production plant or storage facility which distributes or markets the material from AEC prograns. 
IAL Ko. 7401-10

Attacinment i

I equals either (1) the incremental production costs of equivalent material in the standard production feed form at the production plant or storage facility which distributes or markets the material from ditC programs or (2) the market price of salable or purchasable material FOB that AEC site, whichever is higher.

$D$ equals the cost of direct disposal of the material as waste including any additional costs of preparartion or pacikaging the material as a waste over and above that required if the material is to be recovered, shipping to the disposal site and final disposal. The initial packaging and labeling operations and the measurement or anaiysis of the material for the purpose of qualitative or quantitative description shail not be included as part of etther the recovery cost (C) or the disposal cost (D). Such packaging and analysis is to be perforned for safeguards and safety considerations even though the materlal may ultimately be determined to be discardable traste.

In applying this formula, an accurate estimate of the quantity of special nuclear material as well as a rellable description of the form and composition of the material relative to recovery processes is extremely loportant. The content and form will determine, to a large extent, the expense of processing and the effictency of recovery which are most influential on the economic balance.

\section{(3) Priortly for Recovery}

Every effor: must be made to assure that material is treated for safe handling and storage. However, first priortty in recovery processing will be given to the treatment of material which cannot otherwise be rendered safe. In the absence of a safety concern, priority for recovery of various lots of scrap will be determined by the CSMO by ordering the material according to the magnitude by which $I+D$ exceeds $C$. If. I is the Incremental cost of new product material and the material is currently belng produced and requirements exceed current production, then any material which satisfles the formula with the factor of incremental cost used should be recovered in preference to any other alternative source since the cost of this material will be lower than any other source. If I Is the imcremental cost of new product material and 
the macerial is currently being produced but only for the purpose of stocipiling against forecast requirements, then scrap materials should be processed to the extent that the material contributes to meeting the forecast and current recovery capacity is available to add this material to the stockpile.

\section{(4) Unrequired Material}

If new product naterial is not currently being made and there is no requirement for the material, the management disposition shall be based upon retaining the resource at minimum cost against possible future demands and processing the material when such demands wartant the recovery.

\section{(5) Retention in Storage}

The decision to retain matertal in storage will be based upon the relative economics of storage cost versus the present worth of anticipated future market price which the material can be expected to have under the AEC's long-rahige forecest. Such inventory optimizatIon will be conducted by the CSMO.

\section{Procedures}

The following procedure has been prepared to detail the steps used in determining the disposition of scrap nuclear materlal In the AEC's scrap management program.

a. Material is identified as scrap by the generating site when: (a) it is not clearly a disposable waste, (b) It arises in a form that is no longer usabie in the program to which it is assigned, (c) it has been determined unusable in other programs in its present form (ref. Appendix 7401, B., Part III, E.), and (d) 1 t cannot be restored to a production or other feed form in local scrap recovery or recycle operations on a current basis.

b. The material should be processed to a form that will assure safe storage and handling in all subsequent operations if not already in such a form. As soon as the material can be consolidated, the generating site will determine the composition and evaluate the nuclear material contained In the material for safeguards accountability purposes and to provide data for the economic determination of retention or recoverability. In addition to evaluation 
TAI) $\because 0.74-I R$

of nuclear material content, the material will also be examined to develop a technical description that will permit suitable recovery or disposal processes to bi specified and the material will be sorted to provide reasonably homogen:aus lots with respect to reprocessing requirements. Muterial will be packiged in nonccmoustible primary containers suitable for subsequent storage, transportation and handling and labeled to provide information on its nuclear material content, composition and origin.

c. An estimate of the cost of disposal of the material as waste as well as the cost of any additional preparation, packaging, handling and shipping to a site to be designated by the CSMO will be prepared by the generating site for Inclusion in a declaration of the scrap material and request for disposition.

d. The declaration, including the above data, will be forwarded to the CSYO designated for the material as follows: for plutonium-239, Richland Operations office; for enriched uranfum, Oak Ridge Operations office; for plutonium-238, Savannah River Operacions vificc; Eor the Diviston of Waste and Scrap Magement, Headquarters, wil determine appropriate disposition of the material in question. Spectflc designations of CSMO's will be made for other materials if required by WSM.

Coples of all declarations should be forwarded to the Division of Waste and Scrap Management and the cognizant program division at the time they are sent to the CSMO.

e. Upon recelpt of the declaration, the CSMO will develop an estimate of the overall recovery cost for the material to determine the approprlate disposition in accordance with scrap management policies. Using these estimates of cost and the anticipated yield of recovered materlal, the CSMO w111 determine if the material is indeed economically recoverable and is to be shipped to the CSMO or other location for recovery or storage or 1 is to be disposed of directly as a waste material by the generating site. The cSMO will obtain information on incremental production cost and market price or other authoritative value for the material from the approprdate Headquarters program or staft division with the concurzence of the office of the controller, through WSM. The CSMO w111 provide a statement of thetr analysis of recoverability to the scrap generator and the Division of Waste and Scrap Management, Headquarters, along with copies of the instructions it issued to the generating site for disposition of scrap material declared to them. 


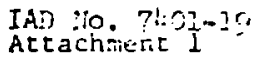

May 26, 1971

f. The generating site will prepare and ship the material in accosdance with approved sinipping regulations and the 1nstructions provided by the CSMO or alternatlvely will dispose of it as waste. Completion of thase actions is confirmad to the Division of Waste and Scrap Management, Headquarters, referenced to the original declaration, and completes the responsibility of the scrap generator for disposition of the particuiar scrap materials.

g. Material determined to be recoverable will be assigned an appropriate priority for processing by the CSMO. Recovery operations will be optimized to yield the recovered product at lowest unit cost to meet current and forecasted requirements. Any and all material which is required to meet current demands and which can be recovered at an incremental cost less than the sum of the incremental unit cost of new procuct plus direct disposal cost should be considered for recovery

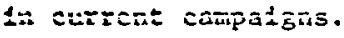

h. Material in storage will be continually reviewed by WSM ard the CSio to determine if it is still economically justifiable to maintain it in storage for future recovery. If not, the material will be surveyed for disposal as waste. The status of materlal pending recovery will be reported quarterly by the CSMO to WSM. 